10-3-2019

\title{
Making "The Garden City of the South": Beautification, Preservation, and Downtown Planning in Augusta, Georgia
}

\author{
J. Mark Souther \\ Cleveland State University, m.souther@csuohio.edu
}

Follow this and additional works at: https://engagedscholarship.csuohio.edu/clhist_facpub

Part of the Public History Commons, United States History Commons, and the Urban Studies and

Planning Commons

How does access to this work benefit you? Let us know!

Publisher's Statement

Copyright SAGE publications. Published by the Journal of Planning History, a SAGE journal. All rights reserved.

Original Citation

Souther, J. M. (2019). Making "The Garden City of the South": Beautification, Preservation, and Downtown Planning in Augusta, Georgia. Journal of Planning History. https://doi.org/10.1177/1538513219873277

\section{Repository Citation}

Souther, J. Mark, "Making "The Garden City of the South": Beautification, Preservation, and Downtown Planning in Augusta, Georgia" (2019). History Faculty Publications. 109.

https://engagedscholarship.csuohio.edu/clhist_facpub/109

This Article is brought to you for free and open access by the History Department at EngagedScholarship@CSU. It has been accepted for inclusion in History Faculty Publications by an authorized administrator of EngagedScholarship@CSU. For more information, please contact library.es@csuohio.edu. 


\title{
Making "The Garden City of the South": Beautification, Preservation, and Downtown Planning in Augusta, Georgia
}

\author{
J. Mark Souther'
}

\begin{abstract}
This article illuminates how a smaller southern city engaged broader planning approaches. Civic leaders, especially women, pushed and partnered with municipal administrations to beautify Augusta, Georgia, a city with extraordinarily wide streets and a long tradition of urban horticulture. Their efforts in the 1900s to 1950s, often in concert with close by planners, led to a confluence of urban beautification, historic preservation, and downtown revitalization in the 1960s. This coordinated activity reshaped Augusta's cityscape, exacerbated racial tensions, and enshrined principles of the City Beautiful, Garden City, and parks movements long after they receded in large cities, influencing the work of nationally prominent planners commissioned in the 1970s and 1980s.
\end{abstract}

\section{Keywords}

Augusta, Georgia, City Beautiful, historic preservation, downtown planning, streets, parks, garden cities, women, race, Savannah, I. M. Pei, American City Corporation

In February 1965, John Remington, an Augusta, Georgia, newspaper columnist, was planning a city tour for a visiting European artist. "I knew what he wanted," the columnist wrote, "for most European cities have their characteristic personalities... So I had to think rather carefully as to whether Augusta did indeed have its own personality, and, if so, what I could show him to demonstrate it." Remington contemplated an "Old South" tour, but Augusta's "landmarks were too interspersed with buildings of the same repetitious pattern to be seen in almost any American city." He considered "the luxurious [sic] green growth which marks our Greene Street," but this too was an isolated feature. Then he thought of the Savannah River and the Augusta Canal, but neither came close to matching San Antonio's riverside promenades. The columnist concluded, "I feel quite sure that no distinctive city gained its image without some careful planning."1

Remington's disappointment was actually the by-product of a cityscape that failed to justify Augusta's long-standing nickname, "The Garden City of the South" (see Figure 1). Coined in the

\footnotetext{
I Cleveland State University, OH, USA
}

Corresponding Author:

J. Mark Souther, Cleveland State University, 2I2I Euclid Ave., RT 1319, Cleveland, OH 44II5, USA.

Email: m.souther@csuohio.edu 


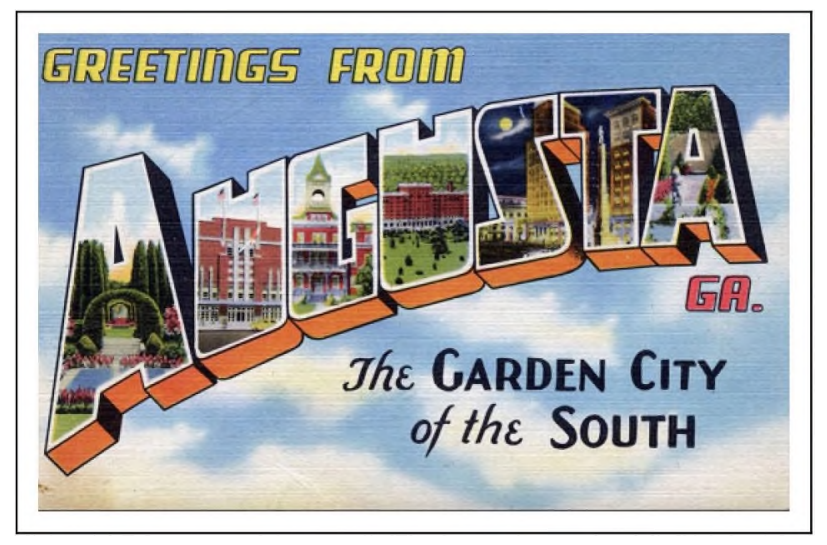

Figure I. Augusta, Ga., "the Garden City of the South" postcard, ca. 1945. Author's collection. By the 1920s, the nickname became firmly entrenched in the community and was repeatedly and persistently invoked for many decades thereafter.

1910 s by Julia Lester Dillon, the first female landscape architect in the South, and adopted by Augusta boosters in 1924, the slogan conjured the images of tree-shaded boulevards, verdant parks, and manicured residential sections. ${ }^{2}$ Dillon's city nickname, to be sure, was not wholly without substance. Augusta's pair of nearly 170-foot-wide boulevards-Broad Street and Greene Streetwere impressive products of an eighteenth-century gridiron plan. By the early twentieth century, boosters touted Broad Street as the widest principal downtown street in the United States after Canal Street in New Orleans, while the Augusta Chronicle effused that the mansion-lined Greene Street was "the Euclid [A]venue of Augusta," a reference to Cleveland, Ohio's famed "Millionaires' Row." 3 The center greens on Greene Street and on the residential sections of Broad were fashioned into parks in the early 1900s. The "Garden City" moniker also drew upon extraordinary estate gardens and Fruitland, the South's oldest commercial nursery, which popularized azaleas and camellias as landscaping plants ${ }^{4}$ (see Figure 2).

However, even in the $1930 \mathrm{~s}$, let alone by the $1960 \mathrm{~s}$, the "Garden City" slogan reflected aspiration more than reality. In addition to a disastrous central-city fire, the effects of suburbanization, urban disinvestment, and sporadic maintenance of public properties and rights-of-way further fractured any semblance of aesthetic cohesion. Apart from "the Hill," the fashionable suburban district that formed around a late nineteenth-century winter resort atop the "fall line" escarpment west of the central-city, Augusta neither measured up to its reputation nor enjoyed significant success in embodying its slogan, but it was not for lack of interest (see Figure 3).

This article examines planning practices in a smaller southern city in the twentieth century. ${ }^{5}$ It finds that those who planned Augusta were informed by broader planning practices associated with the City Beautiful, Garden City, and parks movements, but it also complicates some of the most fundamental scholarly understandings of those movements. The City Beautiful in Augusta reflected the constraints present in a smaller city, resulting mostly in "small plans" of the sort Daniel Burnham eschewed. Like the women described by Bonj Szczygiel, Augusta clubwomen embraced and often launched improvements that could be implemented without prohibitive cost, especially in concert with municipal government, and combined iteratively to effect a broader change. These Augustans did not distinguish but instead melded elements of the City Beautiful, Garden City, and parks movements. In addition, civic actors such as Dillon contributed to beautification but also to other, more prosaic forms of municipal housekeeping. ${ }^{6}$ 


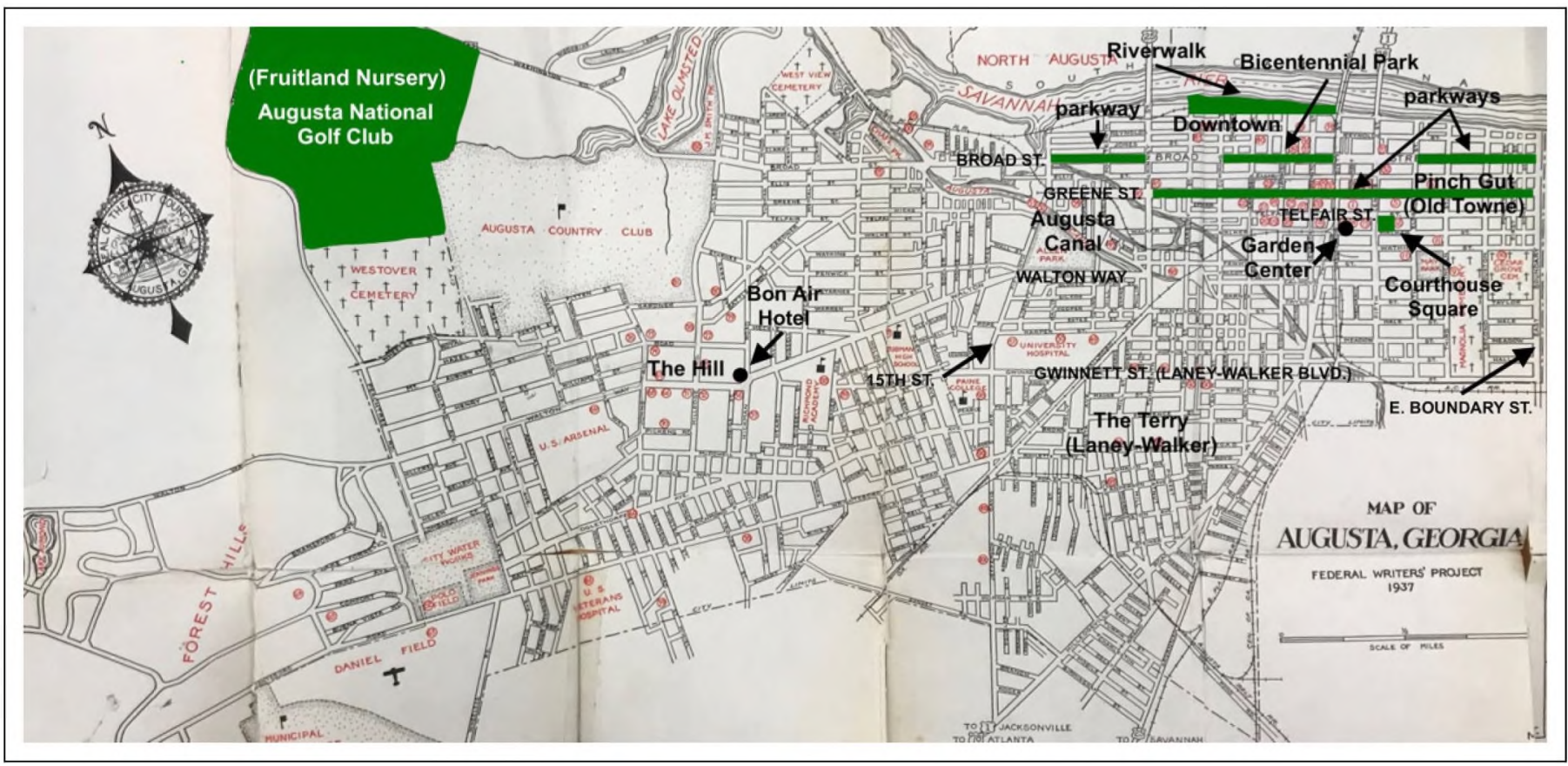

Figure 2. Map of Augusta, 1937. Federal Writers' Project, Augusto (Augusta, GA: Tidwell Printing, 1938). Author's annotations show locations described in this article. Note that some of these locations postdate the map. 


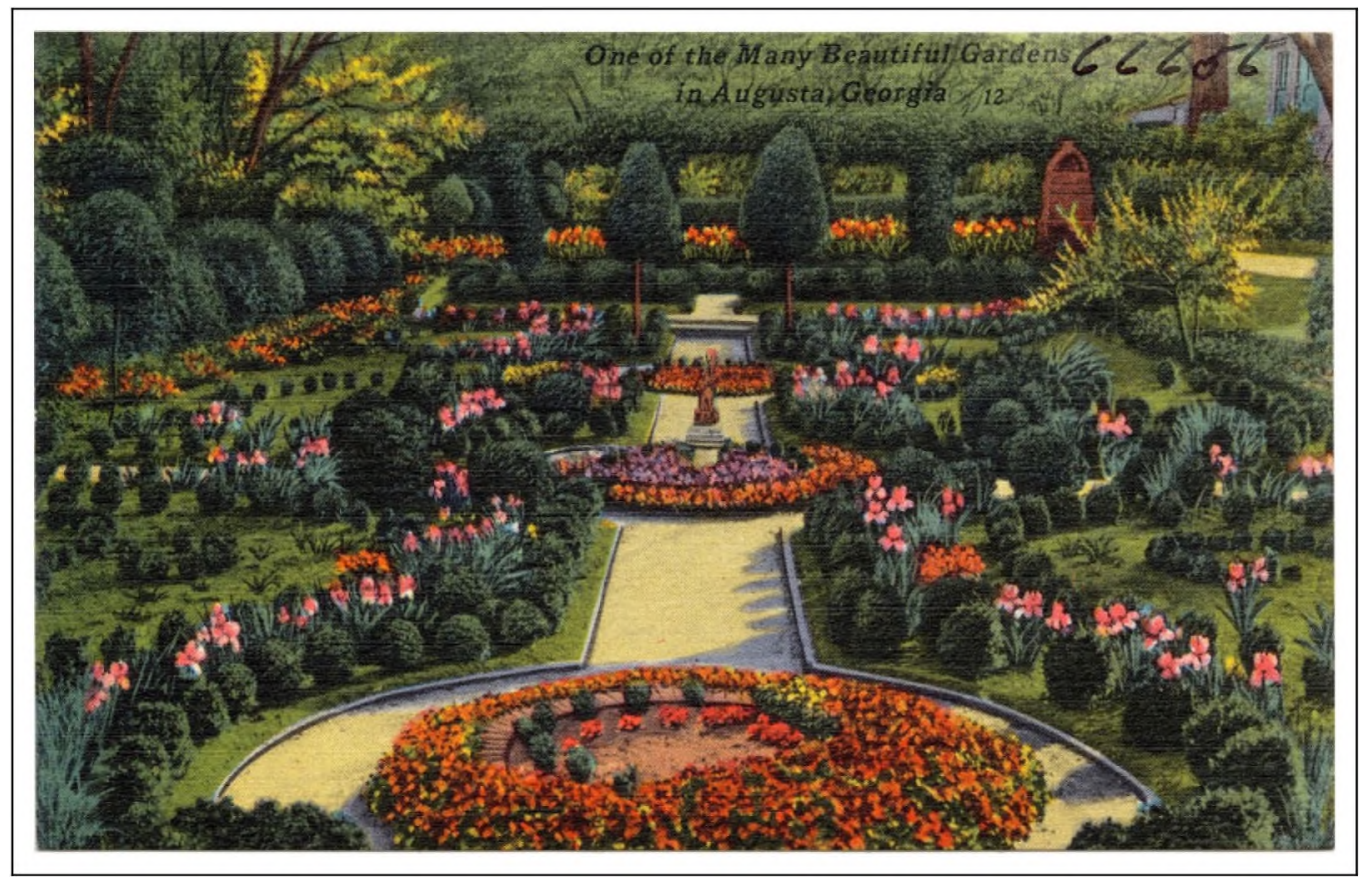

Figure 3. Augusta garden postcard, ca. 1935. Tichnor Bros. Postcard Collection, Boston Public Library, https:// ark.digitalcommonwealth.org/ark:/50959/w3763b9/p. After the disastrous 1916 fire, the Hill section of the city became the most significant concentration of private estate gardens. The garden depicted here was that of Rodney S. and Tracy Cohen. Ms. Cohen's aesthetic inclinations extended well beyond her own garden. She was also instrumental in the larger city beautification movement in Augusta.

At least in Augusta, then, planning did not turn decisively from the City Beautiful to the City Practical in the 1920s." An alliance of clubs and city hall continued to cultivate "The Garden City of the South," largely drawing on their own understandings of the planning principles they hoped to implement. On the rare occasions when they sought outside planning expertise, mainly between the 1930s and 1960s, Augustans turned to planners from Atlanta, Savannah, and Athens. This reliance on nearby practitioners may have reinforced Augustans' tendency to find inspiration in Savannah, long the state's most exemplary planned city and, by the 1950 s, the focus of a large-scale historic preservation effort. $^{8}$

The persistence of the "Garden City of the South" ethos well beyond the heyday of early twentieth-century planning paradigms prepared Augusta for a later blending of city beautification, historic preservation, and downtown planning efforts in the $1960 \mathrm{~s}^{9}{ }^{9}$ Out of this coordinated planning, Augusta leaders began to consult both nearby experts and nationally recognized planning firms in the 1970 s and 1980 s, possibly reflecting a compulsion to demonstrate their ability to reverse a worsening central city decline. Although the longtime cooperative campaign for beautification that had relied on business and government leaders' willingness to work alongside women's organizations broke down, the Garden City ethos proved indelible and shaped subsequent plans.

Another important thread weaves through Augusta's story. Daphne Spain has found that women felt motivated to bring a semblance of physical orderliness to cities in a time of mass immigration. ${ }^{10}$ Perhaps Augusta's civic-minded women were similarly moved to shape the appearance of a city that was between 40 percent and 50 percent African American throughout the period under consideration, with the vast majority of blacks living in sections of the city that had unpaved streets and 
substandard housing. As with planning efforts elsewhere, race and racism played a powerful role in shaping how Augusta would be improved and for whom. Fragmentary but compelling evidence shows that African Americans sought to contribute to and benefit from city beautification within the constraints of Jim Crow, but for the most part, they and their homes remained in the shadow of the "Garden City of the South."

Before continuing, it is worth a few words to contextualize a city that may be little known to most planning historians. Augusta was founded in 1736, just three years after Savannah, making it Georgia's second-oldest city. Situated along the Savannah River on the South Carolina border, Augusta was the second capital of Georgia, from 1786 to 1796 . It was the nation's forty-second largest city in 1830 , with a population greater than all but eleven southern cities and larger than Nashville and St. Louis. By the late nineteenth century, it ranked as the nation's second-largest inland cotton market after Memphis and became a leading textile city and a winter resort of some national renown. However, Augusta simultaneously fell further and further behind relative to the most dynamic "New South" cities. Its population of nearly 40,000 in 1900 ranked third in Georgia, but Atlanta was now more than twice as large despite having been smaller than Savannah and Augusta just a quarter century earlier. By the time Remington was planning his tour, Augusta was only about one-eighth of Atlanta's size. Finally, it is also worth noting that the available primary sources for Augusta are considerably more limited than in larger cities. Therefore, apart from a thorough collection of materials created by the city's historic preservation organization, this article draws preponderantly on newspaper articles, plans and reports, and city council yearbooks and lacks rich sources such as municipal or organizational correspondence that might more fully elucidate motivations and inclinations.

\section{Beautification Efforts in the 1900s to I920s}

Soon after the Hill became a noted winter resort, local and outside commentators extolled the potential they saw for Augusta to realize Garden City and City Beautiful ideals, part of a broader supposition that southern cities could achieve such ideals with far less effort than northern cities. To that end, Augustans contemplated and sometimes carried out beautification initiatives by the early twentieth century. In 1901, Mayor Jacob Phinizy urged the plotting of landscaped "squares" in the rectangular centers of each block of Greene Street. Responding to his call, residents, especially women, planted and tended flowers and shrubs after the "city forces" (convict laborers) graded and sodded the parkways, and residents in one block raised funds for the city to build an ornamental fountain like those found in some Savannah squares ${ }^{11}$ (see Figure 4). In 1903, Col. D. B. Dyer, a streetcar and real estate tycoon from Kansas City, shared his vision for a circular boulevard to connect the nascent Greene Street parkway with existing and prospective parks. ${ }^{12}$ Inspired by George Kessler's Kansas City park and boulevard system, with which he was well-acquainted, Dyer also sought to promote his considerable real estate holdings on the Hill. After building streetcar lines that tied the suburbs to downtown Augusta, Dyer decided to take advantage of the emerging fascination with automobiles. ${ }^{13}$ He downplayed the windfall he and other suburban real estate developers would get from the public subsidy (and chain gang labor) required to build the boulevard, instead of emphasizing its purported benefits for the city. "Augusta," Dyer wrote, "has a large population which indulge little hope of advancement, and it is our duty to supply the best facilities within our power and the refining influence of parks." Dyer's boulevard never reached fruition because he could not obtain sufficient commitments from investors or from the county commissioner of roads, whose convict labor force was always stretched thin maintaining existing roads ${ }^{14}$ (see Figure 5).

The boulevard scheme, which the Augusta Chronicle promoted without luck for several years, was hardly the last effort to employ modern planning principles. A 1909 article in the American 


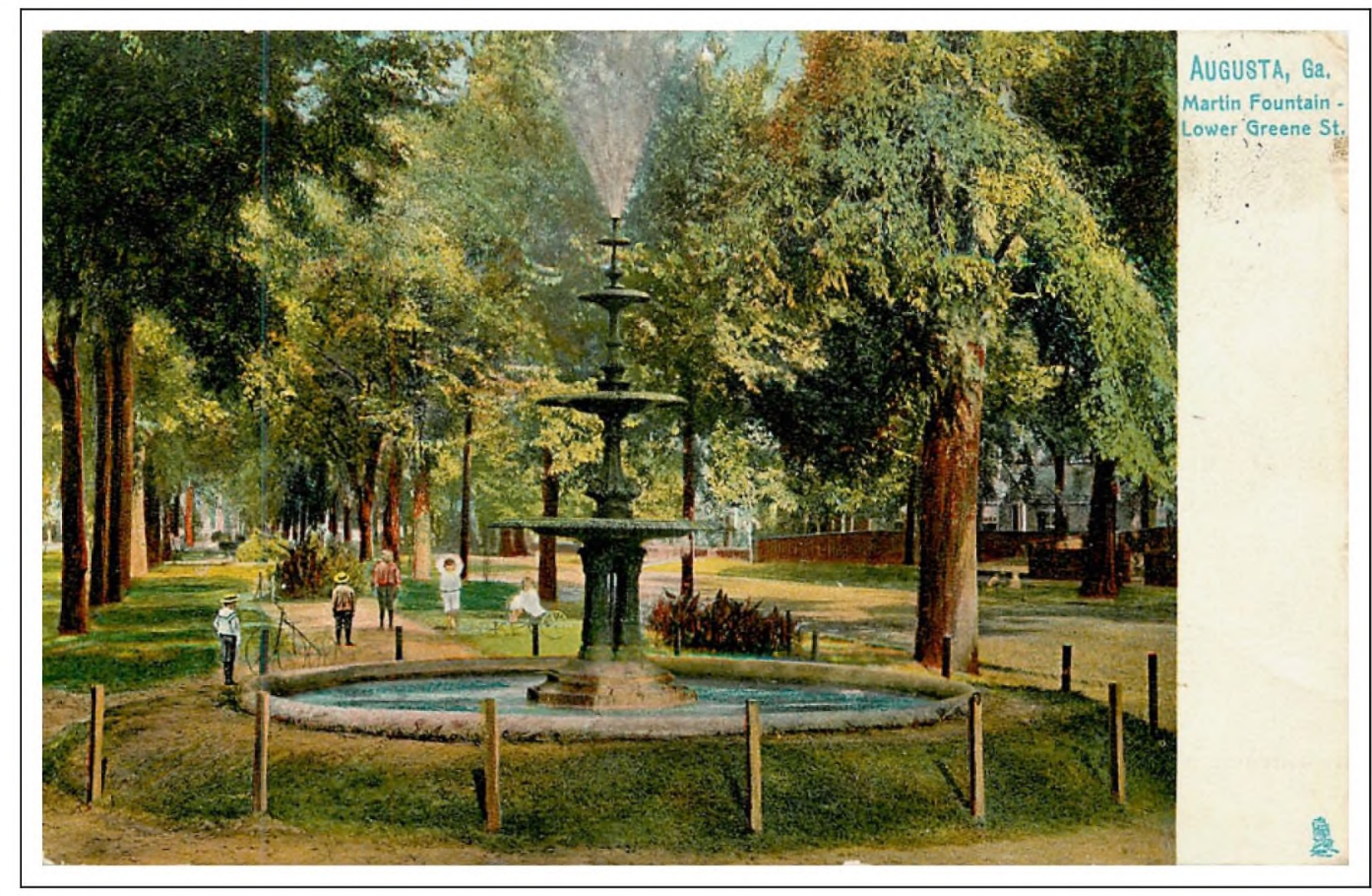

Figure 4. Greene Street postcard, ca. 1907. TuckDB Postcards, http://tuckdb.org/items// I 3833. Funded by subscriptions, the Martin Fountain memorialized a former Augusta mayor. It was part of a sustained cooperative effort between the city government and private citizens to transform the centers of each block of Greene Street into "squares" reminiscent of those found in Savannah.

Architect frowned upon the city's architecture (a startling contrast to the appreciation that would develop later) but was much more impressed with newer houses being built on the Hill and wished that "Augusta proper [would] be more in character with the excellent standard set by this recent suburban work." However, it acknowledged that the central city's "wide, well-shaded streets offer a most attractive setting for a "City Beautiful"" and urged city leaders to "make Augusta one of the first southern cities" to embrace the movement. It argued that even Augusta's downtown spine, Broad Street, was "practically a clean slate" with no "monstrous edifice" too expensive to remove, apart from the Confederate Monument in its center, one of those "with which many southern cities have been afflicted." 15

The Chronicle regularly championed a City Beautiful program in the 1900s and 1910s. During Mayor Thomas Barrett Sr.'s administration, the city created Barrett Plaza as a dramatic entrance to Union Station. The federal government erected a Renaissance Revival-style courthouse and post office on the east side of the space, while the Plaza Hotel opened on the west flank of this intended civic center. Drawing on material supplied by the Chamber of Commerce, the Christian Science Monitor commented that Barrett Plaza's "concreted walks, verdant lawns, and palmetto trees greet the eyes of the incomer and make a pleasing first impression," pronouncing it the start of "a CityBeautiful movement in Augusta."16

City Beautiful campaigns failed in most cities to move beyond limited group plans of public buildings arrayed around plazas, yielding to municipal housekeeping initiatives, often spearheaded by women. ${ }^{17}$ But Augustans did not forsake beautification. In February 1916, Julia Lester Dillon partnered with the Augusta Chronicle and the Augusta Woman's Club, formed three years earlier, on 


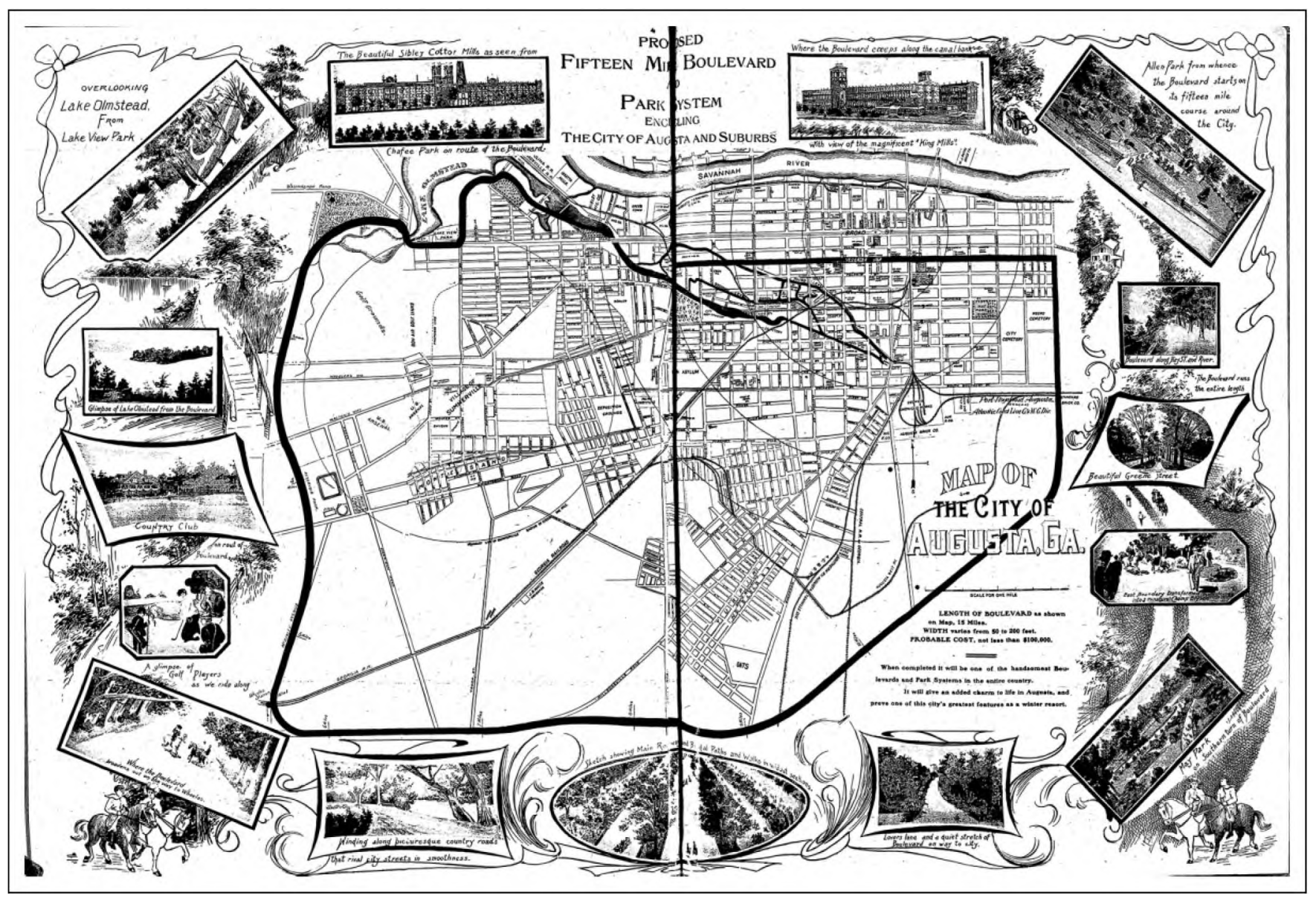

Figure 5. "Proposed Fifteen Mile Boulevard and Park System." Augusto Chronicle, March 25, 1906. Influenced by the work of George Kessler in Kansas City, Col. D. B. Dyer tried to interest Augusta leaders in creating a park and parkway system that would have extended the newly "parked" Greene Street into a circular boulevard to connect to existing and prospective parks. 
a "City Beautiful Campaign" that focused on beautifying private property in the city. The collaborators announced a contest with ribbons and cash prizes for the most attractive gardens. Hoping to prevent the wealthy from dominating the contest, they planned to give seven prizes in each of the city's six wards. ${ }^{18}$ Just over two years after city council had rejected a proposed racial zoning ordinance in a city where residential segregation was hardening without such formalities, the contest added a separate "Negro Gardens" category. This action came only after the Rev. Dr. Charles T. Walker, the nationally known pastor of Tabernacle Baptist Church, put the Chronicle on the spot by presenting a US $\$ 20$ contribution for this purpose from a winter tourist from New York-one of many who were attracted by Walker's impassioned sermons and the church's famed gospel choir. ${ }^{19}$ Although African Americans comprised about 45 percent of Augusta's population, the number of prizes allotted to black contestants was only equal to that of one ward. Separate and unequal, the contest ended up giving US $\$ 275$ to white winners and only US\$45 to black winners. ${ }^{20}$

Dillon's vision suffered a setback when a fire broke out on March 22, 1916, in the Dyer Building (built by Col. D. B. Dyer) in downtown and, fanned by strong winds, engulfed twenty-five city blocks. In a single night, 746 buildings, including many of the finest mansions with the most elaborate gardens along Broad and Greene Streets, were reduced to rows of ghostly brick chimneys ${ }^{21}$ (see Figure 6). The fire accelerated population flight to the Hill. For many old families, the downtown neighborhoods became reminders of their loss, and they busied themselves cultivating a sense of community on the Hill rather than in town. Marie Dugas Battey, a member of one such family, went downtown to bring her two sisters "to the Hill so they would not have to see the devastation" of their childhood home. Battey returned to the ruins to dig up flower bulbs to plant in her garden on the Hill. $^{22}$

Although the contest continued, the burned section of First Ward (also known as Pinch Gut) worried civic leaders. In June 1916, Dillon complained that the city had yet to clean up the burned district. On lower Broad and Greene Streets, she pointed to "piles of burned trees" and "grass growing waist high on the swards that should be kept like a park." "In the name of the city beautiful," she demanded, "will not the city council order the burned area cleaned up?"23 Echoing Dillon, in a speech to the Augusta Woman's Club in 1921, James Bailie Jr. of Fruitland Nursery lamented that Greene Street, which had been the showplace of Augusta until the fire, had since "lost much of its former beauty." He asked whether Augusta leaders were "less enterprising than other people," arguing that as they pursued development, they abdicated responsibility for "our trees, our parks, and our flowers." Bailie said that women were the city's only hope for creating a more attractive city. ${ }^{24}$

Beautification efforts remained sporadic in the 1920s. Annual appropriations to the city's Trees and Parks Commission (TPC) seldom permitted more than routine upkeep, and even that was lacking at times. In city council annual reports, TPC superintendent $J$. W. Westmoreland complained of the absence of a municipal nursery large enough to support a proper tree-planting program, shortages of chain gang labor to tend the city's parkways, plant thefts from the city's nurseries, youth vandalism, and infestations of ants. ${ }^{25}$ Another vexing problem was the presence of sycamore and hackberry trees, which lacked strong taproots, on parkways and sidewalk strips. After severe storms felled many such trees, the city council passed ordinances in 1928 that forbade planting these varieties on city-owned properties and prescribed Darlington oaks, a hardy, mostly evergreen tree, to improve the city's street canopies. ${ }^{26}$

\section{The Garden Club Movement and City Beautification in 1930s to 1960s Augusta}

Central-city neighborhoods continued to suffer neglect in the 1920 s as newly developed allotments on the Hill captured nearly all of Augusta's residential growth. However, the decade also marked 


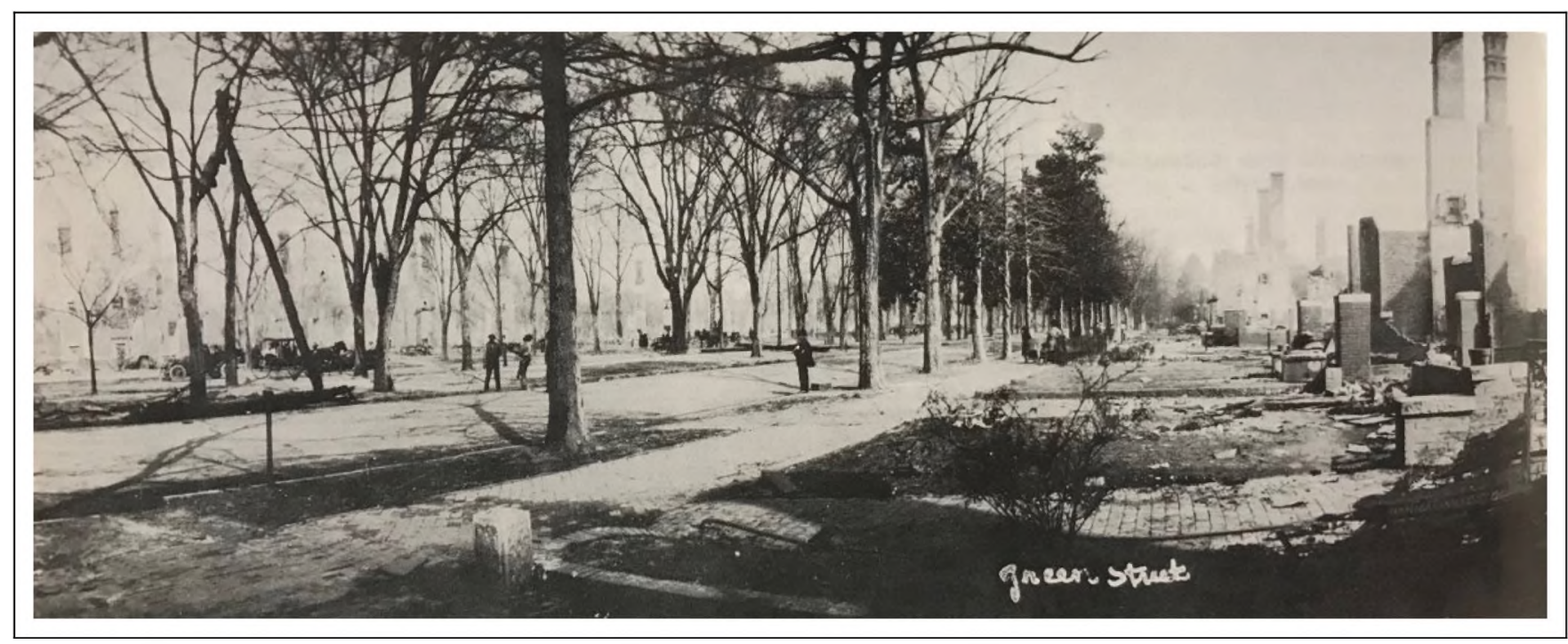

Figure 6. "Greene Street after the Great Fire of 1916." Augusta Magozine, Spring 1968. The destruction of much of Augusta's grand residential boulevard hastened the departure of affluent families to the Hill section. Although they relocated to this recently annexed suburban area, a number of them, especially women operating through the Sand Hills Garden Club, later championed city beautification in the older sections of the city including Greene Street. 


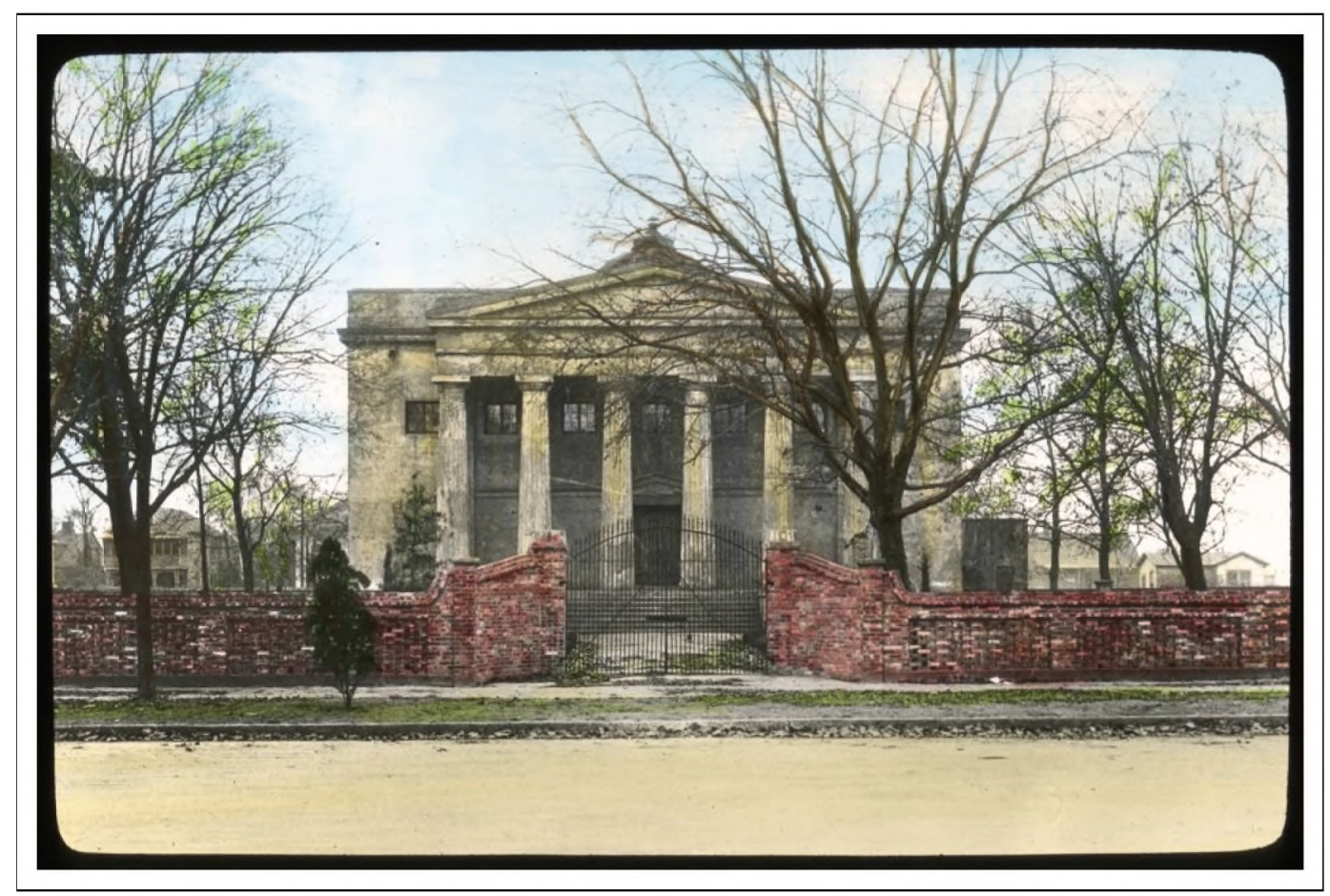

Figure 7. Old Medical College of Georgia hand-tinted slide, ca. 1935. Smithsonian Institution, Archives of American Gardens, Garden Club of America Collection. Built a century before this photo was taken, the Medical College's original building on Telfair Street became an early project of the Sand Hills Garden Club. The club's effort to preserve the building provided space for its own functions while also serving as an anchor for ongoing civic beautification efforts by the club and others.

the origin of what later became an intensive, coordinated campaign to make Augusta "the Garden City of the South." This development owed less to the Chamber of Commerce's use of the slogan than to women's suburban garden clubs that became invested in city beautification. The most influential one, Sand Hills Garden Club, was founded in 1927 at a tea party hosted by Mrs. Joseph McKnight Speer who had moved from Pittsburgh to the historic Goshen Plantation outside Augusta. $^{27}$

More than gardening enthusiasts, Sand Hills Garden Club's women spearheaded an emerging effort to combine city beautification and historic preservation. In 1931, on member Tracy Duncan (Mrs. Rodney S.) Cohen's recommendation, the club leased the old Medical College of Georgia building on Telfair Street, an 1835 Greek Revival landmark. Renamed the Garden Center, it became a meeting place for Sand Hills and, later, for the Augusta Council of Garden Clubs (ACGC). The clubwomen, "armed with mops, brooms, buckets, and scrubbing brushes," cleaned up the building and laid out a formal garden of camellias surrounded by ivy and periwinkle and framed by boxwood hedges on its grounds. They used the Garden Center to host the Garden Club of America annual meeting in 1932 and the nation's first annual camellia show beginning in $1933^{28}$ (see Figure 7). The old Medical College was not the first example of historic preservation in Augusta; that distinction belonged to the Daughters of the American Revolution's 1902 renovation of Meadow Garden, the onetime home of Declaration of Independence signer George Walton, as a house museum. Nevertheless, thanks to its location on the edge of downtown, the Medical College-turned-Garden Center was the nucleus of an eventual, coordinated central-city revitalization. 
In addition to making the Garden Center a demonstration of preservation and beautification, Sand Hills and other garden clubs became increasingly active partners with the city government in trying to beautify Augusta. During the Great Depression, when mounting city debt forced greater economy, a pair of developments encouraged and supported beautification on a level not previously seen. First, Bobby Jones, an amateur golfer from Augusta who achieved renown by frequently beating many of the best professional players, founded and helped design the Augusta National Golf Club on the site of Fruitland Nursery in 1932. In 1934, Jones, leveraging his reputation, staged the inaugural Masters Tournament at Augusta National, which brought thousands of visitors to the city. With the promise of hosting the Masters annually, city government and business leaders now had more reason to support efforts to minimize the disparity between the manicured grounds of the former Fruitland Nursery, filled with thousands of exotic trees and shrubs, and a deficient cityscape marred by years of uneven attention. Second, in 1935, the Works Progress Administration (WPA) breathed new life into Augusta's beautification efforts. In stark contrast to the early 1930s, when city council annual reports offered only that the TPC was being "efficiently run," by 1936, the city was suddenly more active than ever before in embellishing its parks. ${ }^{29}$

Emboldened by the infusion of federal funds, Mayor Richard E. Allen Jr. launched a citywide beautification program and convinced the city council to form the Augusta Beautification Commission, whose charge was to devise a long-range beautification plan for parks and parkways and work with garden clubs and other organizations to coordinate similar activity on private property. ${ }^{30}$ The Augusta Chronicle applauded Mayor Allen's campaign and, pointing to the 164-foot-wide Broadway in Columbus, Georgia, the paper urged a similar parkway on the downtown section of Broad Street to make it "the talk of visitors from all parts of the country." In another editorial, it argued that there was no reason Augusta could not match "the beautiful squares and parks of Savannah and Macon." Referencing the city's nickname, the editorial ended, "Known as the Garden City, let's make Augusta such in fact." 31

The Augusta Beautification Commission enjoyed a brief period when city initiatives matched Mayor Allen's enthusiasm. Between 1936 and 1939, the commission planted some 2,300 Darlington oaks citywide and planned to hire W. H. Robertson, the longtime superintendent of trees and parks in Savannah, to make a comprehensive plan for Augusta. ${ }^{32}$ Soon, however, Robertson sent his regrets, so Augusta's planners turned instead to Hubert Owens who headed the University of Georgia landscape gardening department. After arriving in Augusta in April 1937 with his assistant Cynthia Wiley, Owens averred that no city with such a "wonderful layout" had been so neglected. In July, Owens and Wiley's resulting survey recommended "elaborate, comprehensive, and uniformed [sic] beautification" of the central city in the seven blocks to the south of Broad Street between East Boundary Street (the eastern end of the city) and Fifteenth Street, plus along Walton Way to Milledge Road on the Hill. ${ }^{33}$

Unsurprisingly in the Jim Crow South, the Owens-Wiley plan omitted "the Terry," Augusta's largest African American neighborhood, just south of the survey area. Incidentally, only two months after the plan was unveiled, the Home Owners' Loan Corporation issued its residential security map of Augusta, which "redlined" the entirety of the Terry, along with all smaller residential pockets in the central city except several blocks in Pinch Gut. Augusta's large African American population resulted in its being the fifth most thoroughly redlined American city ${ }^{34}$ (see Figure 8). Just as Walker had pressed the Augusta Chronicle to include blacks in its 1916 garden contest, black real estate broker S. L. McCoy approached city leaders in 1938 with a plan to extend beautification planning to Gwinnett Street, the principal thoroughfare in the Terry that ran parallel to and twelve blocks south of Greene Street. Many years after most main streets in the predominantly white sections of Augusta were paved, Gwinnett remained a dirt street until the promise of WPA funding spurred improvement. Mayor Allen pledged city support and named S. L. McCoy chairman and R. A. Dent of Dent's 


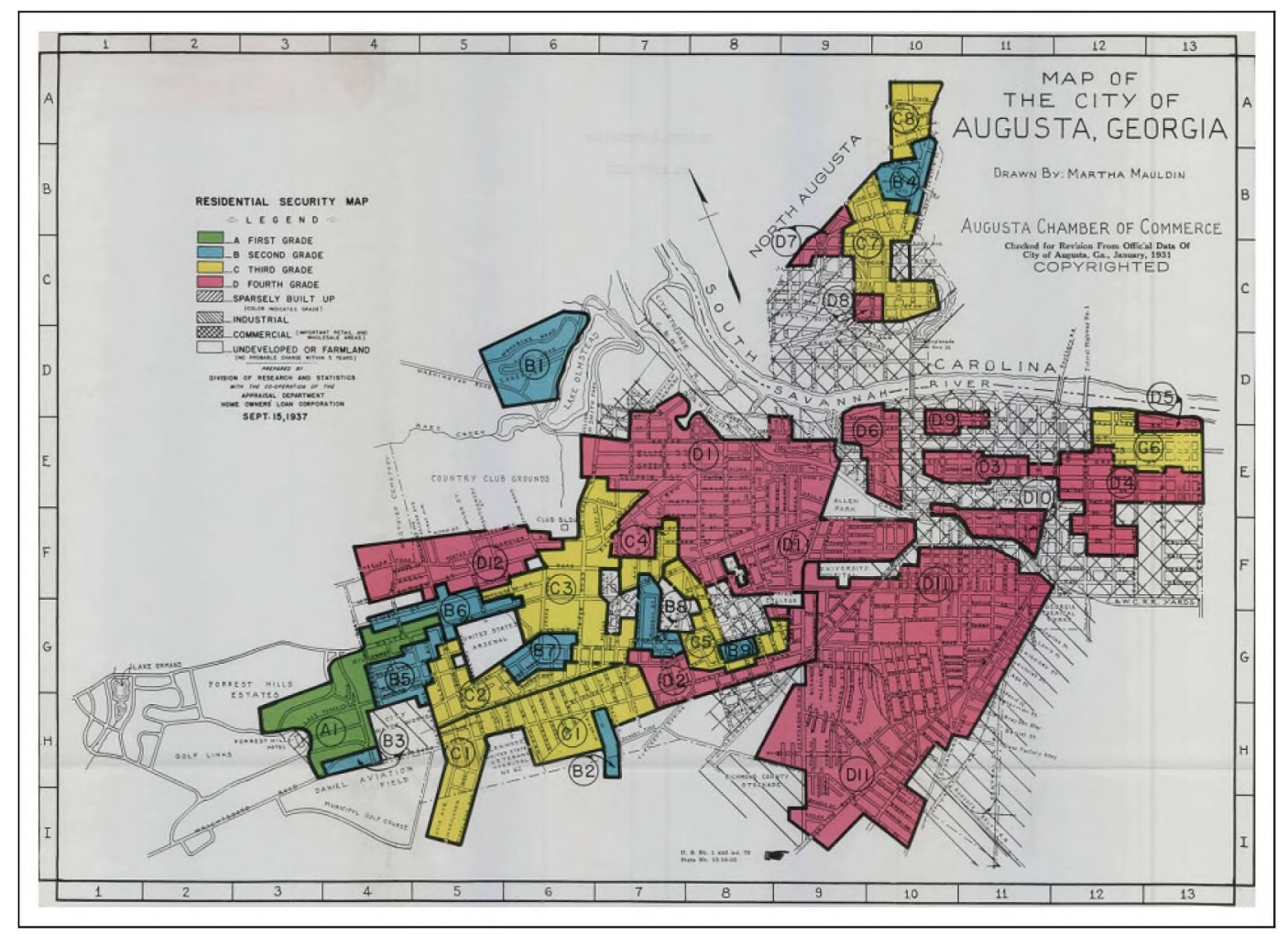

Figure 8. Residential security map of Augusta, 1937. https://dsl.richmond.edu/panorama/redlining. The Home Owners' Loan Corporation made maps such this one for many US cities beginning in the mid-1930s. The socalled Fourth Grade, colored red, later became well-known to urban historians as a codification of longstanding discriminatory real estate industry practices. The red zones on this map, including "the Terry" (Augusta's largest African American neighborhood) in the lower right quadrant of the map, comprised the majority of the city limits of Augusta. Indeed, Augusta ranked fifth nationally as the most thoroughly redlined city by proportion. Most of the First through Third Grades (depicted in descending order of presumed stability and desirability in green, blue, and yellow, respectively) were confined to the Hill on the lower left quadrant of the map. Apart from North Augusta, South Carolina (upper right quadrant), the only other part of Augusta rated "Third Grade" was found in the "Pinch Gut" neighborhood along lower Broad, Greene, and Telfair Streets (center right), much of which was rebuilt after the 1916 fire and later became the "Olde Town" district.

Undertaking, the oldest black-owned funeral home in Georgia, vice-chairman of a committee to organize property owners and tenants. ${ }^{35}$

The outcome of the Jim Crow companion to the Owens-Wiley plan was not recorded, but the street paving project it was to accompany proceeded with federal assistance. At a festive dedication, one municipal official commented that the local government "recognizes that one-half of the population is composed of Negroes" and that it had taken into account "the entire population" in its planning. Then, he hit upon one of the more honest motives for the city's concern: "Disease knows no color." A black preacher at the dedication, Rev. R. C. Calhoun, put a different spin on the matter: "[T]he white people can't have a great city for themselves without having a great city for us." 36

After WPA support receded in 1939, the city dialed back its appropriations for beautification. ${ }^{37}$ Between 1940 and 1948, the city planted only 185 Darlington oaks, a sharp drop from the average of eleven trees per week in 1936-1939. Far from creating a unifying aesthetic, the city did little more 
during this period than removing dead trees and sowing ryegrass to keep Augusta's parkways green in the winter tourist season. In 1945, a study of the city government commissioned by the Augusta Citizens Union called attention to "municipal housekeeping" shortcomings. In addition to the growing problem of urban blight, the report pointed out that 62 percent of city streets remained unpaved and even the city's prized parkways, so central to Augusta's image, were "very untidy." 38

The Augusta Chronicle editorialized later that year that, as it vied with other southern cities for a share of postwar growth, the city should not overlook one civic improvement that it claimed could be made relatively easily: giving attention to Augusta's "main streets that COULD be made the talk of the nation." Echoing the municipal government report, the editorial warned against suburban complacency while the central city decayed:

Owning a beautiful home in a favored section of the city is not enough.... One cannot withdraw into beautiful surroundings and exclude from sight the dirt and ugliness that are now characteristic of a large part of the city of Augusta. Nor can any defense be made to visitors to Augusta who regard with amazement the dirty canal banks, the littered streets, the over-grown, trash-encumbered vacant lots; the cluttered-up, down-at-the-heels streets that now mar the appearance of even the more favored sections of the city.

Rather than demanding that city officials remedy their failings, the editorial once again laid the onus on women - essentially a very willing group of white women on the Hill - to take the lead through their garden clubs in "prodding" "the men" to act. It called for the city to restore the longdefunct beautification commission and work closely with an alliance of garden clubs to undertake cooperative public-private improvements. ${ }^{39}$

The late 1940 s and early 1950 s saw a renewed effort for city beautification. The formation of the ACGC in 1948 and Mayor W. D. Jennings's appointment of florist and city councilman James J. Harbin as TPC chairman in 1949 provided the impetus. ${ }^{40}$ With ACGC's encouragement, Harbin ushered in a new era of cooperation between the TPC and garden clubs. Between 1949 and 1952, Harbin oversaw the planting of thousands of azaleas and camellias on the city's parkways and more than 3,500 trees citywide. Harbin's program even encompassed Gwinnett Street in "the Negro section," although no description exists of its improvements there. Over the next several years, the city council's annual report proclaimed, "Great strides have been taken in an effort to make Augusta the Garden City of the South." 41

Concerns about the vitality of central Augusta mounted in the 1950s. Although the metropolitan area experienced a brief boom with the nearby construction of the Savannah River Plant, a plutonium, uranium, and tritium facility to support atomic bomb production, the city itself was nearing the end of its successes in using annexation to capture suburban growth. The 1960 census would reveal the first drop in the city's population, and Augusta leaders started fixating on the same combination of factors - urban decay and the accessibility and attractiveness of downtown - that marked many cities. Affluent old-line Augustans also had a different fear that rapid metropolitan development and an influx of newcomers might imperil Augusta's languorous Old South aura, tight-knit social circles, and historic landmarks. ${ }^{42}$

\section{The Confluence of Preservation, Beautification, and Downtown Revitalization}

In June 1965, just four months after the Augusta Chronicle reporter John Remington's lament about Augusta's disconnected attractions, Savannah preservationist Walter C. Hartridge Jr. urged a group of concerned Augustans to follow Savannah's example by reinvesting in their historic cityscape. Inspired by his suggestion to start on Telfair Street, the group formed the Historic Telfair 
Foundation. ${ }^{43}$ Marie Dugas Battey Bush of the Sand Hills Garden Club, widely credited as the driving force behind starting the organization, explained, "I lived with the tragedy of the Augusta fire all my life," but, unlike her mother, for whom the old city was irreparably ruined, Bush learned to see Augusta's potential. Although the Historic Telfair Foundation existed in name alone until September, when it incorporated as Historic Augusta Inc., the organization remained committed to spearheading preservation on Telfair Street. ${ }^{44}$

The choice of Telfair Street as a starting place might seem surprising, given the outsize attention that had long been accorded to the beautifying the parkways on Broad and Greene Streets. Although Broad and Greene Streets were more important thoroughfares, neither had structures as old as some on Telfair. Since the 1920s, various groups besides Sand Hills Garden Club had become stewards of historic buildings on Telfair. ${ }^{45}$ Like the iterative, incremental improvements they made to the landscape, their investments preserved landmarks that might anchor a historic district. In 1966, Carl Feiss of the National Trust for Historic Preservation called Telfair Street "a unique architectural ensemble" but lamented that its landmarks stood in a fragmented urban landscape. Feiss urged "tying them together by landscaping and walkways." Inspired by Feiss, Historic Augusta arranged for the women of the Junior League of Augusta to inventory a ninety-six block area in and around downtown, which led to the decision to create a "pilot project area" bounded by Greene, Fifth, and Walker Streets and the Gordon Highway, an elevated expressway that narrowly skirted the historic Old Government House that anchored the pilot area. In keeping with Feiss's recommendations and the well-known approach taken in the 1930s Colonial Williamsburg reconstruction, the preservation body decided to keep only five of eighteen existing buildings in the block because structures constructed after the Civil War were not yet deemed historic. ${ }^{46}$

The pilot project concept also reflected contemporary notions about seeding urban redevelopment and creating protective buffers for downtown that were inseparable from preoccupations with race and property values. Indeed, Walter Hartridge had recently been involved in Historic Savannah Foundation's Troup Ward pilot project, which was "walled off" from a nearby African American neighborhood. ${ }^{47}$ In 1965, the Augusta-Richmond County Planning Commission (ARCPC) had set a similar tone when it adopted a recommendation to encourage housing improvements in Pinch Gut, severed from downtown by the construction of the Gordon Highway eleven years earlier. Augusta planning director Lawrence Connor argued that Pinch Gut was "needed to provide customers for the downtown business district" and, borrowing language long used in real estate and planning circles, he added that the Gordon Highway, May Park, and Magnolia and Cedar Grove Cemeteries afforded "an excellent "buffer zone' to protect the residential district.",48

The pilot project area - later named Courthouse Square - was an attempt to mimic Savannah's squares, much as landscaping, fountains, and monuments adorned each "green" in the center of Greene Street. This effort was reinforced each time consultants and invited speakers from Savannah made comparisons between their city and Augusta. Historic Savannah Foundation's executive director Reid Williamson spoke at the first Historic Augusta annual meeting in 1967. Williamson inspired his audience with slides showing Savannah preservation successes and his recommendation of a revolving fund like Savannah's to support purchasing, preserving, and reselling architecturally significant properties. ${ }^{49}$ Historic Augusta commissioned Robert P. Nicholls, a professor at the School of Environmental Design at the University of Georgia, to prepare a site plan with generous garden spaces. ${ }^{50}$

At a time when preservationists often differed substantially from urban planners, business elites, and city officials over how to revitalize central cities, Augusta evinced an impressive degree of consensus in the late 1960s. ${ }^{51}$ In 1968, the ARCPC released a multivolume city plan that included a historic preservation and city beautification plan, and it helped prepare a downtown plan. Both plans illustrate a commonality of interest that helped unite downtown renewal, preservation, and beautification. They also reflect a close working relationship between the 
ARCPC and various stakeholders. In order to contextualize the 1968 plans, it is useful to briefly revisit earlier approaches.

As in many other cities, interest in downtown renewal in Augusta reflected growing worries about the impact of suburbanization. Even before World War II, concerns emerged about traffic congestion and availability of parking in downtown, finally leading to the reluctant decision to add parking meters in the center strip of Broad Street in $1946 .{ }^{52}$ However, meters did little to deter those bent on parking close to their intended destinations. By the early 1960 s, worsening congestion prompted the first concerted effort to improve downtown accessibility and attractiveness. Rather than relying on Broad Street to serve as what one observer called "the most expensive parking lot in the nation," the city government considered various alternatives: removing centeraisle parking to add to its six lanes or creating a landscaped parkway that would make Broad Street "the showplace of the United States." 53

In 1962, a Georgia Tech planning student prepared an Augusta downtown study under the guidance of the ARCPC director. To solve the problem of a street too long for shoppers to stroll from end to end, the study recommended concentrating retailing between Sixth and Eleventh Streets, while banishing parking to off-street garages to speed traffic. It proposed creating a pedestrian mall on Ellis Street (between Broad and Greene Streets) and encouraging Broad Street stores to open new entrances onto the mall. The plan called for demolishing buildings for several blocks perpendicular to Broad Street just outside a newly compressed business district to make room for park belts and garden apartments and connecting these green corridors to a linear park that might replace railroad tracks, warehouses, and a levee now considered obsolete thanks to upriver flood-control protections. If these actions were taken, the study promised, suburbanites would be attracted to live downtown ${ }^{54}$ (see Figure 9).

The 1968 downtown plan, like the 1962 study, aimed to create a unified downtown. It gave special attention to downtown Augusta's "unique physical pattern," especially its linear business district spanning 6,000 feet along Broad Street, where pedestrians had to cross six lanes of traffic and four of angle-parked cars. In contrast to Greene Street, the center of Broad was "a sea of hot asphalt and concrete, punctuated by row on row of parking meters" (see Figure 10). Like the 1962 study, it also prescribed a riverfront greenbelt, where it imagined apartment towers overlooking the Savannah River. In contrast to the 1962 study's call for abandoning Broad Street to the automobile and reorienting its stores toward a rear mall, the new plan recommended adding midblock crosswalks with landscaped "safety islands," building department store expansions using air rights above Broad Street to create anchors in the 600 and 800 blocks, and further segmenting the linear district with two pedestrian malls traversing the middle of the 500 and 900 blocks of Broad Street. Reflecting work by Paul Muldawer, an Atlanta-based architect responsible for a number of Savannah building restorations and a consultant to Historic Augusta Inc., the 1968 downtown plan recommended adaptive reuse of nineteenth-century commercial buildings in the 500 block of Broad $^{55}$ (see Figure 11).

Just as the downtown plan made connections to a nascent preservation movement and longstanding beautification efforts, ARCPC's concurrent preservation and beautification plan was careful to mesh with the downtown plan. It called downtown revitalization "the preliminary move toward ... a beautiful, contemporary city." In contrast to the well-tended "squares of Savannah and the Ansonborough area of Charleston," it saw Augusta's "isolated structures" in African American neighborhoods as the most endangered. It endorsed relocating scattered historic homes to Courthouse Square to attract "people who will make a contribution to the civic life of the community." This remedy assumed the black community's incapability of contributing beneficially to property values, commercial profit, and civic life. Indeed, as the plan illustrated graphically in its maps, there was virtually no overlap between the largely black area tagged for eventual urban renewal and the largely white residential and downtown commercial area cordoned off for preservation. $^{57}$ 


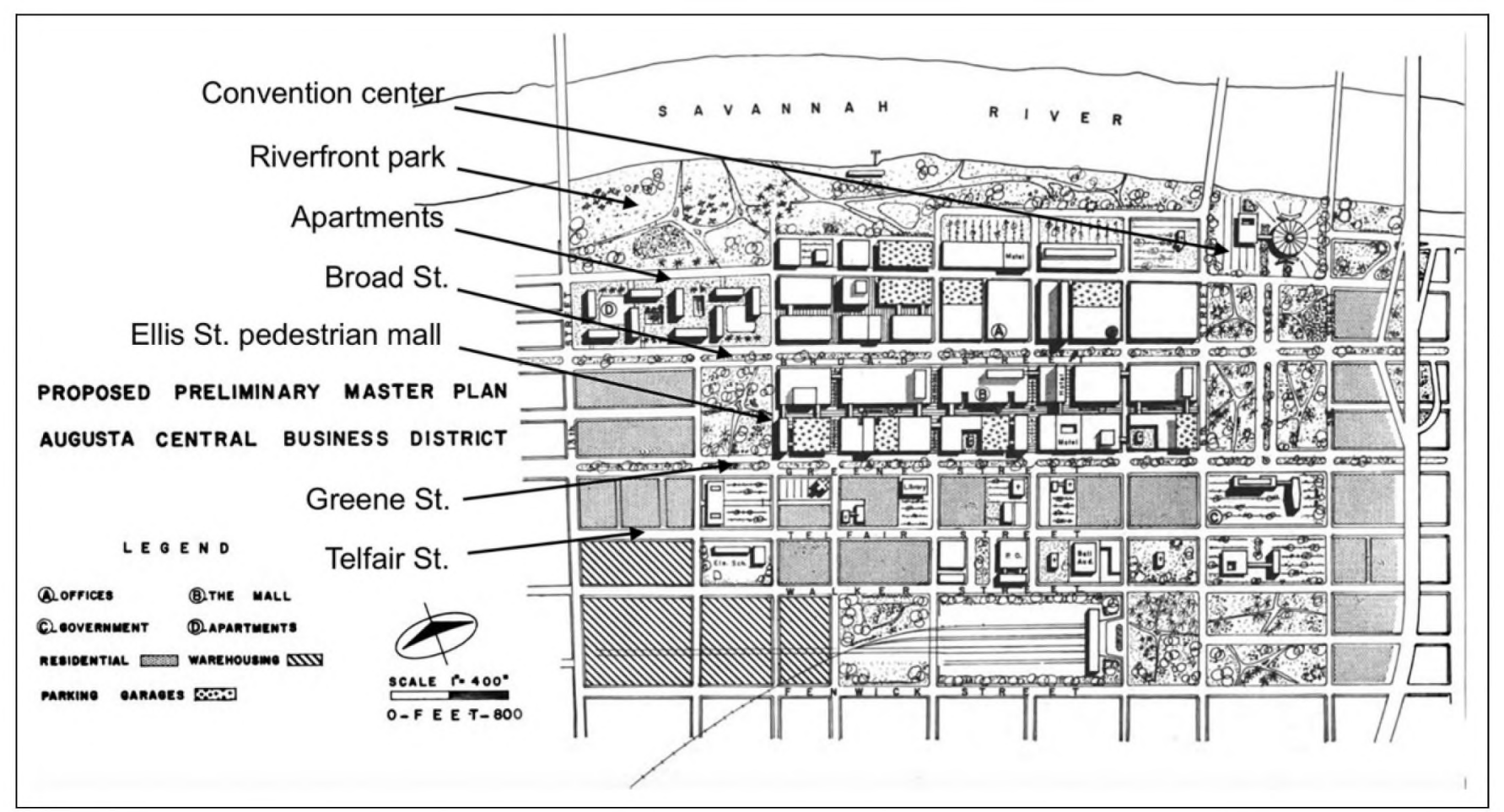

Figure 9. Downtown plan map, 1962. Ramsis W. Baghose, Central Business District Study, Augusta, Georgia (Augusta, GA: Augusta-Richmond County Planning Commission, 1962), 29, University of Illinois at Urbana-Champaign via HathiTrust Digital Library, https://catalog.hathitrust. org/Record/102 185420. This plan proposed concentrating and cordoning off the downtown district (center) using parks and green spaces. A pedestrian mall was envisioned along Ellis Street, the narrow east-west street running parallel with and between Broad and Greene Streets. The strip of land along the Savannah River (top) anticipated the American City Corporation's Bay Street Esplanade plan twenty years later, which was implemented and renamed Riverwalk Augusta on its dedication in 1988. 


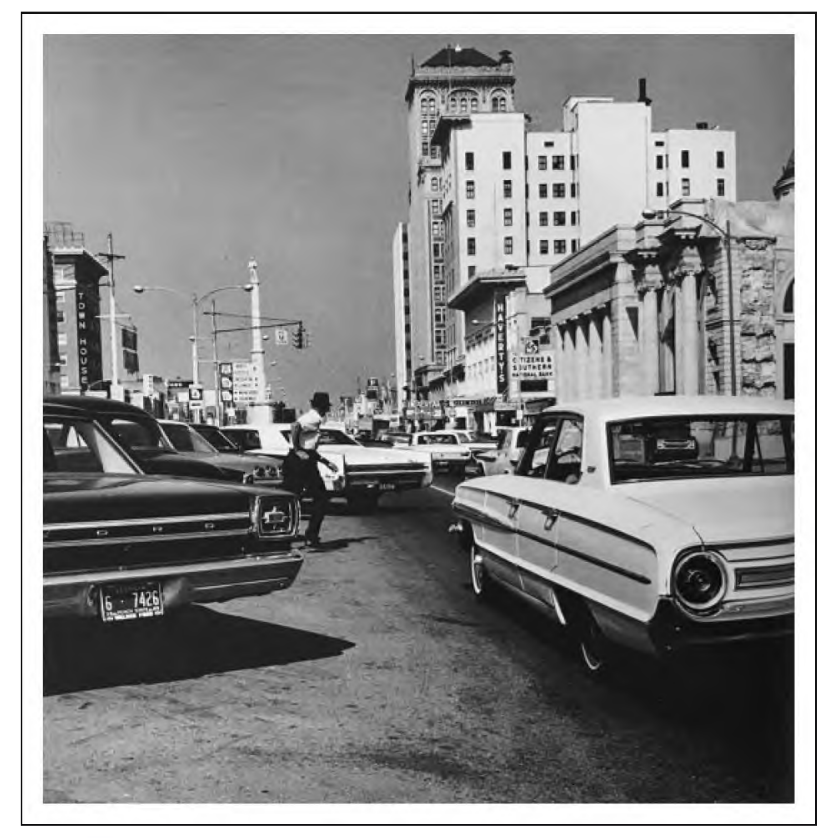

Figure 10. Broad Street, 1968. Augusta Commercial Areas Study Committee, Downtown Augusta: A Plan for Expansion and Revitalization of the Central Area of Augusta, Georgia (Augusta, GA: Commercial Areas Study Committee of Augusta, 1968), 12, Augusta-Richmond County Public Library. A man dodges a car backing out of a center-aisle parking space on Broad Street. Long a civic bragging point, providing the most driving space of any street in the United States also proved a safety hazard. Many years of attempts to remove center parking had met with merchant protest. The 1968 plan recommended transforming the center of Broad Street into a landscaped parkway and replacing the lost parking spaces with off-street garages.

In turn, the ARCPC's plan reinforced how Historic Augusta's leadership viewed its pilot project. Norman C. Larson, its first executive director, penned "A Master Plan for Historic Augusta," which was issued in August 1968, just weeks after the ARCPC plan. As in that plan, Historic Augusta's master plan pointed to the lack of a concentrated historic cityscape and prescribed a combination of focused restoration efforts and relocation of vulnerable buildings. Dismissing the possibility that landmarks might be important assets in their original milieus, Larson took a dimmer view, writing that, "[1]ocated in the poorer sections of the community, their eventual deterioration and loss seem preordained." He rejected the idea that they might be touchstones for revitalization, adding that in situ restoration "seems impractical because of a variety of factors including absentee ownership, indifference of residents, the improbability of the racial complexion of the area ever changing, and the inability of these sections to attract conscientious, affluent citizens." Once moved, he argued, such buildings could be "attractively grouped in a landscaped setting," where they "should attract the type of developer we need to succeed in our venture." 58

Implementation of these plans proved difficult, thanks to uncertainty about who would become the next mayor, an economic slump caused by the phase out of Vietnam War training at Fort Gordon, and growing hostility toward privileging downtown over marginalized neighborhoods. Beverly Carter, effectively a downtown plan chairman without a committee, conceded that "we're pulling the wool over our own eyes if we build up downtown Augusta, while 10 to 12 blocks away we've got unpaved streets, houses without toilets, [and] some without windows." In a similar vein, African American city councilman Grady Adams "cast a mild pall over the annual League of Women Voters legislative luncheon" in December 1969 when, in answer to a question about progress on downtown 


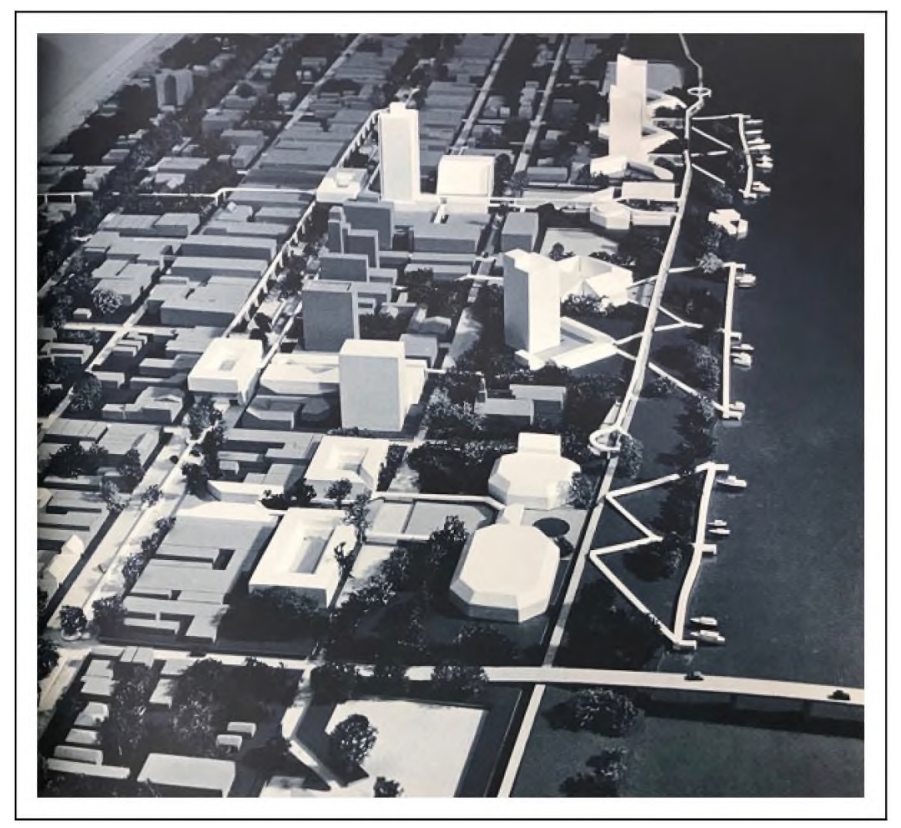

Figure II. Downtown plan model, 1968. Augusta Commercial Areas Study Committee. Downtown Augusta: A Plan for Expansion and Revitalization of the Central Area of Augusta, Georgia (Augusta, GA: Commercial Areas Study Committee of Augusta, 1968), 23, Augusta-Richmond County Public Library. The 1968 downtown plan included a linear park with a pedestrian path lined by apartment towers and a convention center along the Savannah River. It also imagined a mall-like plaza with reduced traffic lanes on Broad Street, along with air-rights expansion buildings for two department stores and twin elevated "people mover" transit ways above the street's sidewalks.

revitalization, he averred, "I haven't thought much about the problems of downtown Augusta, when the problems of the ghetto community aren't given thought." 59

Soon thereafter, the "problems of the ghetto community" became inseparable from those of downtown. On May 11, 1970, a group of African American protesters assembled around the courthouse on Greene Street. Inside, black community leaders were meeting with the head of the county commission to voice concerns about the county jail, where Charles Oatman, an intellectually disabled sixteen-year-old black youth facing murder charges, died two days earlier. Police claimed that Oatman fell out of his bunk, but the coroner detected signs of systematic abuse and a fatal blow to the head. Outside, the crowd ripped down and set fire to the Georgia flag, which incorporated the Confederate battle flag. The Southern Christian Leadership Conference (SCLC) local chapter head implored them to withdraw to a rally at Ninth and Gwinnett Streets, but instead they "surged" in the opposite direction. More than 500 participants "created havoc on Broad, marching through a department store and turning over display counters" before returning to Gwinnett Street where some set fires, hurled rocks at passing cars, and even pulled people from their vehicles and beat them. Within hours, Gov. Lester Maddox, a demagogue who was quick to blame the Black Panthers and a "communist conspiracy," ordered 1,200 National Guardsmen and 150 state patrolmen into Augusta with live ammunition. Before the civil disturbance was over, six unarmed African American men lay dead, all shot in the back with "double-aught buckshot" by the Augusta police. ${ }^{60}$

The rebellion shattered any illusion that Augusta had no race problem. A report on the so-called race riot charged that whites viewed the city from the "manicured confines" of the Hill, "securely entrenched behind the crabgrass curtain." They still went downtown to work and shop, but they 


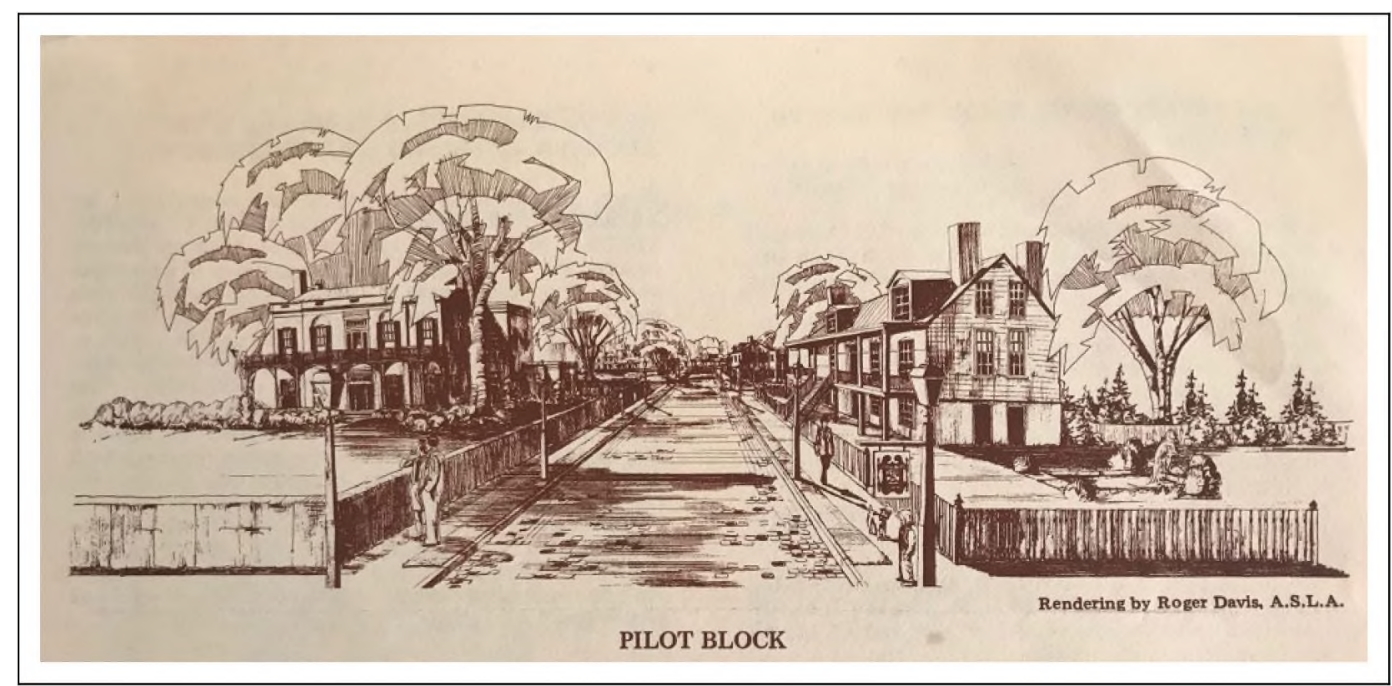

Figure 12. Pilot block (Courthouse Square). News Bulletin 5, no. I (October 1972), Historic Augusta Inc. Inspired by Savannah's squares, Historic Augusta Inc. sought to "curate" a group of historic houses either preserved on site or moved from other, more neglected sections of the city with the hope of seeding preservation-based urban revitalization in and near downtown Augusta.

seldom encountered the shacks in the Terry. They were immune to problems such as the nation's highest school dropout rate and the 67 percent black poverty rate that plagued Augusta's two "allNegro" census tracts. ${ }^{61}$ The uprising also contributed to the inertia of downtown revitalization, beautification, and preservation planning. As Historic Augusta Inc. held its fourth annual meeting at the Garden Center on May 27, 1970, members must have felt mixed emotions as Paul Muldawer presented a slide lecture on how Savannah's successes in using preservation as a central-city revitalization tool could be repeated in Augusta. A Historic Augusta newsletter article later noted that the violence "left a heavy pall of smoke and gloom over any prospect of restoring an area in turmoil. ${ }^{, 62}$ For the next several years, the preservation organization struggled to find buyers for its restored buildings in Courthouse Square.

\section{Seeding a Greener Downtown: Broad, Greene, and Telfair Streets in the I970s}

The effort to realize the Garden City of the South quickened after Mayor Lewis Newman took office in 1973. Historic Augusta's pilot project area, Courthouse Square, finally began to take shape, and a new revitalization impulse appeared to bring new life to the five-year-old downtown plan. By May 1973, Historic Augusta had made all necessary property acquisitions in Courthouse Square, relocated a donated historic Sand Hills cottage to the site, obtained garden designs, received a National Trust for Historic Preservation loan, and obtained a commitment from the county to pave Courthouse Lane. ${ }^{63}$ Two years later, following the Historic Augusta annual meeting, Mayor Newman cut the ribbon to dedicate Courthouse Lane, where gas lamps and brick sidewalks lined the new cobblestone alley. Within two more years, Historic Augusta could also point proudly to the lush garden setting of Courthouse Square ${ }^{64}$ (see Figure 12).

A block to the north, Greene Street languished. Calling to mind Julia Lester Dillon's lament after the 1916 fire, Chronicle reporter Margaret Twiggs observed, "The Green," often likened to Savannah's squares, "is deteriorating, the azaleas have grown into huge bushes, many too large for the 
space they occupy, some obstructing the monuments they surround, and [creating] a hazard for pedestrians." She depicted the parkway as the site of assaults and wished that the city would redirect some funds toward beautifying the Garden City. ${ }^{65}$ In 1974 and 1975, the Newman administration replanted Greene Street with 4,350 dwarf azaleas and introduced an underground sprinkler system and brighter streetlights. ${ }^{66}$ And, for the first time since 1953, after lobbying by local women's garden clubs, the city resumed its tree replanting program in 1976. However, after having removed some 7,600 trees (approximately one per day) over the previous twenty-two years, the program was hardpressed to do much more than restore the canopy along a few main thoroughfares. ${ }^{67}$

Meanwhile, in November 1973, insurance agent and civic leader David T. Peet convinced Mayor Newman to support a downtown "action plan." With the aid of Augusta real estate tycoon and state senator R. Eugene Holley, Peet persuaded businessmen to fund a revised downtown plan. The new Chamber of Commerce-sponsored Downtown Council, with Peet as president, hired I. M. Pei \& Partners of New York to develop an updated "action-oriented" plan with particular focuses on parking and beautification of Broad Street from Sixth to Tenth Streets. At the time, Pei was also designing a new coliseum-civic center, a downtown hotel, and a futuristic, three-story, pyramidal penthouse atop the sixteen-story Southern Finance Building. ${ }^{68}$ The choice of Pei signaled a break from the city's longtime reliance on Georgia planners, perhaps an indication that civic leaders wanted to avail themselves of the wider attention that a prominent planner might bring.

In September 1974, Pei arrived with a detailed scale model of four blocks of Broad Street. The US $\$ 15,000$ model was so large it had to be flown to Atlanta in a 747 jet and transported by an 18 wheeler to Augusta. ${ }^{69}$ According to Pei, his US\$4 million plan would turn Broad Street from "a parking lot" into "a perpetual fair," surely a nod to other revitalization schemes, notably Boston's planned Faneuil Hall Marketplace. Pei believed that Broad Street was too wide for a pedestrian mall and therefore required a unique solution. His plan included a sixty-foot-wide, tree-shaded median with landscaped paths, fountain pools, parking, and geometrical buildings filled with boutiques, eateries, Chamber of Commerce offices, and a visitor center-all while retaining four of the existing six traffic lanes and curb parking. The city, for its part, pledged US\$1 million in lighting upgrades. Business owners promised another US\$1 million through a self-taxing plan for the streetscape transformation. And, to ensure support by department stores that feared the loss of parking, the city planned to build a US $\$ 2$ million parking deck one block south of Broad. ${ }^{70}$

Pei's redesign of Broad Street, named Bicentennial Park to mark its dedication on July 4, 1976, was imagined and described in the context of the city's ongoing bid to lend credence to its Garden City of the South nickname. In keeping with a nearly fifty-year-old local commitment, the planners selected Darlington oaks to line the center parkways. In addition, Pei diminished the visual impact of automobiles by lining the parkway's sunken parking areas with continuous flower planters. Along with its series of vivid renderings, an Augusta Magazine article argued that the street's "brightly colored flowers and lush evergreen shrubbery" would "help Augusta be the Garden City"71 (see Figure 13).

Adding to Pei's modern interpretation of a traditional parkway, Historic Augusta turned its attention to Broad Street after finally selling the remaining Courthouse Square properties that had tied up its revolving fund for most of the $1970 \mathrm{~s}$. While the city government and business leaders had assembled the funding needed to bring an architect of international renown to Augusta, Historic Augusta continued the tradition of tapping in-state practitioners. In 1979, the organization hired University of Georgia School of Environmental Design professor John Linley, who recommended a tree-planting program beyond Bicentennial Park. ${ }^{72}$ Historic Augusta also invited speakers to present on Macon's successful Urban Development Action Grant (UDAG)-funded downtown facade restoration program. With its encouragement, the Newman administration undertook a similar campaign in $1980 .^{73}$ The city's actions emboldened Historic Augusta to purchase, restore, and sell 


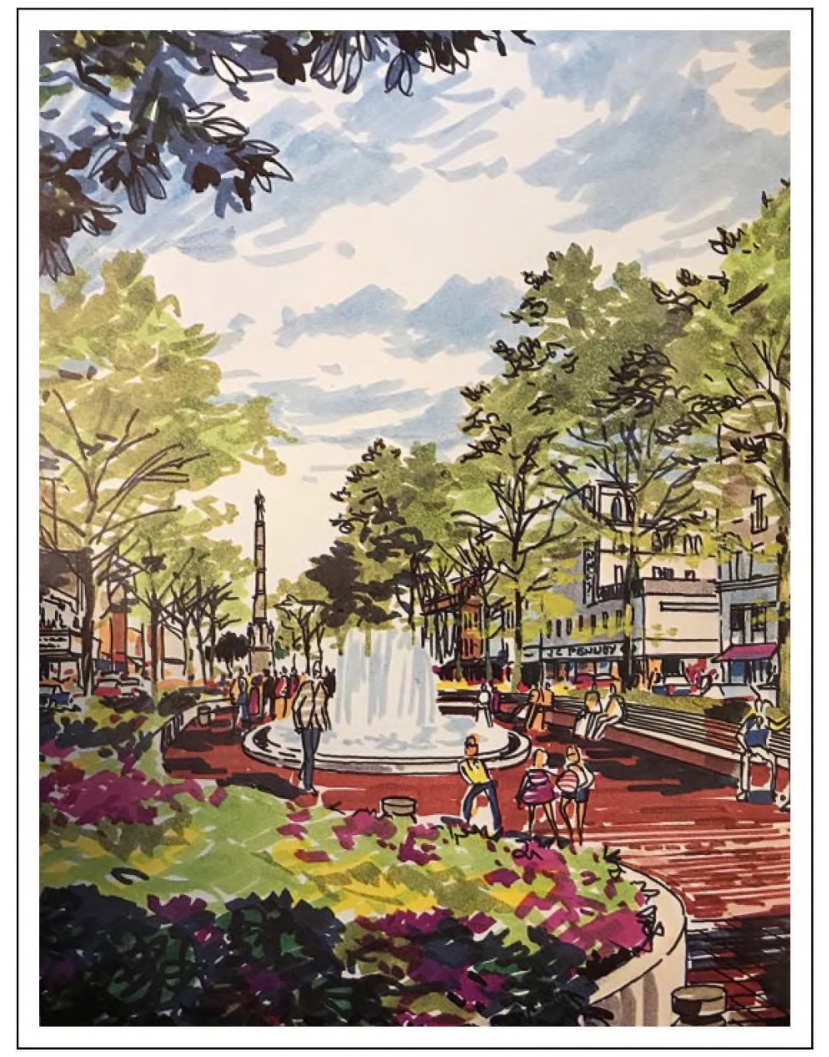

Figure 13. Bicentennial Park rendering. Augusta Magazine (Winter 1976), 27. I. M. Pei's redesign of Broad Street gave Augusta's principal downtown thoroughfare the parkway it had never had, although the park spaces were interspersed with sunken parking bays and even a two-story building that housed a new Chamber of Commerce visitor center and offices. Touted as another step in the realization of Augusta's "Garden City" ideal, the streetscape did little to reinvigorate a downtown that was soon beset by the opening of two large suburban malls.

the historic cast-iron balconied building at 608-612 Broad Street, which had recently housed one of several go-go bars in the 500 and 600 blocks frequented by Fort Gordon servicemen. ${ }^{74}$

Historic Augusta also consulted with Lee Adler of Historic Savannah Foundation on that city's success in beginning to transform a longtime slum into the Victorian District and worked to recast Augusta's Pinch Gut as Olde Town. ${ }^{75}$ In contrast to several years before, when one real estate official told Historic Augusta's president that the Gordon Highway provided "an effective barrier between the subject block [Courthouse Square] and low value residential areas to the east," by the late 1970s, many investors were following the lead of Peter S. Knox Jr. who began snapping up dilapidated Victorian houses as early as $1972 .^{76}$ Along with Historic Augusta's work to establish National Register districts and local preservation zones on Broad, Greene, and Telfair Streets and along the Augusta Canal, Olde Town, and the historic cemeteries to its south helped sketch the outline of a potential six-mile historic corridor. ${ }^{77}$ Augusta's Garden City image had emerged at a time when its best exhibits apart from its parkways-Augusta National Golf Club and estate gardens on the Hill-were largely inaccessible to the public. Improvements along the Savannah River and Augusta Canal would add considerably to the city's network of green spaces beginning in the 1980 s. 


\section{The American City Corporation (ACC) and Augusta's Turn toward the River}

In a single week in the summer of 1978, Regency Mall and Augusta Mall opened in Augusta's western suburbs, introducing more than 1.5 million square feet of new retail space to the metropolitan area. Augusta's lateness in building regional malls - ten to twenty years after many citiesaccounted for the relative resilience of downtown into the late 1970s. However, even Bicentennial Park and the city's facade restoration program were not enough to offset the impact of two malls. Within months after their mall stores opened, Cullum's, Davison's, and White's department stores closed their Broad Street locations. ${ }^{78}$

By 1980, it was clear that Pei's Broad Street plan had failed to stop downtown decline. In that year, a group of business leaders contacted the Columbia, Maryland-based ACC, a subsidiary of the Rouse Company, known for its "festival marketplace" concept including the Inner Harbor revitalization project then underway in Baltimore. ${ }^{79}$ When Edward M. McIntyre was elected in 1981 as Augusta's first African American mayor, he lent enthusiastic support to a public-private partnership to revitalize the central city. In 1982, the city allocated US\$60,000 in Housing and Urban Development (HUD) grant money to match US $\$ 60,000$ offered by a newly formed booster organization called Augusta Tomorrow, enabling the hiring of ACC to prepare a new city plan. ${ }^{80}$

The resulting study drew inspiration, to an extent, from earlier plans. It resembled the 1962, 1968, and 1974 plans in its recommendations for Broad Street. Its call for turning McCartan Street north of Broad into a landscaped courtyard and creating a pedestrian mall on Seventh Street merely updated older ideas. The plan also repeated and modified proposals dating to 1962 to build a hotel and convention center on the riverfront and a landscaped corridor to visually connect the riverfront with the government center on Greene Street, and it included similar proposals to those in 1968 for apartment buildings facing the river. ${ }^{81}$

However, in other ways, the plan was different. Unlike earlier plans that were limited to downtown or even Broad Street, ACC's plan encompassed the entire central city and gave the strongest emphasis yet to turning central Augusta into a more unified, historic cityscape, citing Savannah and Charleston as models. ${ }^{82}$ For example, it acknowledged the revitalization efforts underway in Olde Town and envisioned in the Terry, now known as Laney-Walker, after the city renamed Gwinnett Street as Laney-Walker Boulevard in 1975 to commemorate black educator Lucy Craft Laney and the founding Tabernacle Baptist Church pastor Charles T. Walker. ${ }^{83}$ Laney-Walker had been a focus of Historic Augusta since 1980, thanks to the receipt of a federal grant to support a historic district nomination and black heritage tours, and in 1981, the Trees and Parks department had completed the first systematic tree-planting effort in the neighborhood's history. ${ }^{84}$ It is important to note, however, that Olde Town and Laney-Walker were relegated to "Second Priority" status in the ACC plan. ${ }^{85}$

The most striking disjuncture, however, was the shift in emphasis from Broad Street to the riverfront. While the 1962 and 1968 plans had included riverfront improvements, riverfront development was the centerpiece of the ACC plan. A linear park called Bay Street Esplanade was planned atop the levee and at river level, thanks to planned breaches in the levee. In addition to lush landscaping and pedestrian links to Broad Street, Bay Street Esplanade was to incorporate a visitor center, a boat landing with riverboat restaurant, a housing development, a reconstruction of historic Fort Augusta, and even an International Golf Exposition that might incorporate a replica of Augusta National's eighteenth green, bringing a bit of the most famous but largely hidden symbol of the Garden City into the heart of Augusta. ${ }^{86}$

Riverwalk Augusta, as Bay Street Esplanade became officially known, opened on April 1, 1988 (see Figure 14). In its first few years, the Riverwalk brought large numbers of visitors and locals downtown, especially to festivals, concerts, boat races, and other special events. ${ }^{87}$ These enhanced Augusta's growing reputation in the 1980 s as a beautiful and historic city, a reputation promoted 


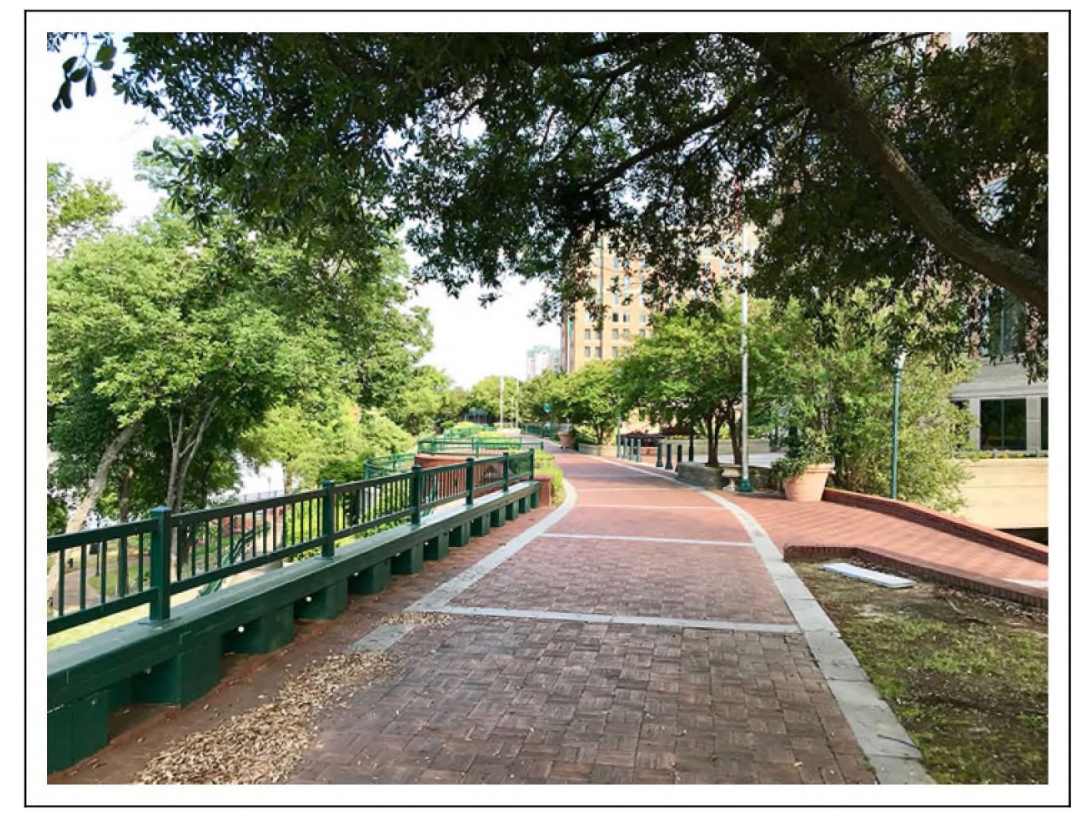

Figure 14. Riverwalk Augusta, 2018. Photo by the author. This significant investment in Augusta's longneglected riverfront was expected to catalyze tourism- and leisure-oriented downtown revitalization. Despite well-laid plans, north-south connectivity with Broad Street never materialized to the anticipated extent. Nevertheless, the Riverwalk remains a major civic asset, and a planned extension will eventually connect the linear park more fully with other parklands.

through the commitments of Augusta Tomorrow, Historic Augusta Inc., and the administrations of Mayor McIntyre and his successor Charles DeVaney. Although the Riverwalk inspired some reinvestment in downtown, it never delivered the anticipated redevelopment of most of the vacant buildings and lots in the two-block stretch between the river and Broad Street. When Augusta and Richmond County consolidated in 1995, the combined government, rather than extending the central city's Garden City ethos throughout Augusta-Richmond County, now found itself distracted by needs that went beyond the old city limits. Maintenance of the Riverwalk sagged, and, worse, it gained a reputation like that of the footpath in the parkway on Greene Street as being unsafe. ${ }^{88}$

\section{Conclusion}

The deep-seated vision of Augusta as a Garden City lingered into the twenty-first century despite continuing to invite unfavorable comparison between vision and reality. Away from its manicured golf links, estate gardens, and parkways, much of Augusta continued to present an ugly face, leading to the increasing use of the derisive nickname "Disgusta," which had first appeared in a 1970 letter to the Augusta Chronicle by a newcomer who thought the city deserved to be called "Disgusta. Garbage City of the South. ${ }^{, 89}$ In 2009 , Augusta Tomorrow released the city's first major master plan since 1982. In keeping with the ideal of a city that reached across the river, a departure from the common assertion that Augusta's downtown lay on the eastern edge of a Georgia-based metropolitan area, the plan characterized Augusta and North Augusta, South Carolina, as "Linked Garden Cities." Reminiscent of Dyer's boulevard, the plan imagined "a system of existing waterways, parks, and greenways which, if properly augmented and connected, will become one of the main attractions to the area." The concept sought to unite Augusta's Riverwalk, Broad and Greene Streets, various 
parks, the Augusta Canal Historic Trail, and the North Augusta Greeneway, a seven-mile multipurpose path on an abandoned railbed that added to surviving remnants of a late nineteenth-century greenbelt system designed by Charles Boeckh. ${ }^{90}$ The challenge, as ever, remained that of making a system out of Augusta's scattered assets to stimulate revitalization.

As posited at the outset, most scholarship on the City Beautiful, Garden City, and parks movements - like planning history scholarship in general - has focused on large cities. This article has suggested that, at least in Augusta, the smaller scale of projects, greater reliance on citizen cooperation, and longtime tendency to filter national planning models through local or close by planners created some variance from the dominant narrative. Augustans' long-term embrace of early twentieth-century planning principles calls into question the standard periodization of these efforts. Was Augusta unique in its melding of concurrent planning traditions? Was it unusual in its persistence in adopting aesthetic improvement as a dominant strand in its planning and economic development? Or were Augusta's planning practices indicative of those in other smaller cities in the South and perhaps elsewhere or of those that formed early economies rooted at least partly in appealing to outside investors and tourists? My own research is extending to Columbus and Macon, two other similarly sized cities along Georgia's fall line. Early indications are that both of these cities shared much in common in their planning practices, although Columbus leaders repeatedly consulted nationally prominent planners such as John Nolen of Cambridge, Massachusetts. ${ }^{91}$ More research is needed to test the resiliency and persistence of early twentieth-century planning ideals and how they eventually informed preservation and downtown revitalization. Only by including smaller cities in these investigations can historians more fully test prevailing assumptions about the place of civic beautification in twentieth-century urban America.

\section{Acknowledgments}

The author would like to thank Francesca Russello Ammon and the two anonymous reviewers who commented on drafts of the article. The author also thanks Tina Monaco and Tina Rae Floyd at Augusta-Richmond County Public Library, Erick Montgomery and Robyn A. Anderson at Historic Augusta Inc., Nancy Glaser at Augusta Museum of History, and Kara Flynn and Tammy Westafer at Augusta University Library Special Collections.

\section{Declaration of Conflicting Interests}

The author(s) declared no potential conflicts of interest with respect to the research, authorship, and/ or publication of this article.

\section{Funding}

The author(s) disclosed receipt of the following financial support for the research, authorship, and/or publication of this article: The research was assisted by funding from the Faculty Scholarship Initiative, Cleveland State University.

\section{ORCID iD}

J. Mark Souther (D) https://orcid.org/0000-0001-8090-7056

\section{Notes}

1. John W. Remington, "As I Wander," Augusta Chronicle-Herald, February 7, 1965, p. 3-F.

2. "Mrs. W. Dillon, Noted Landscape Architect, Dies," Augusta Chronicle, March 25, 1959, p. 2; Bill Kirby, "Nickname Grew from the Truth," Augusta Chronicle, April 9. 2000, p. 1C; Augusta, Georgia. The Garden City of the South (Augusta, GA: Ridgely-Tidwell Company, 1924), box 5, folder "Augusta Resource Material 1900-1973," Augusta Metro Chamber of Commerce Collection (hereafter AMCC), Augusta Museum of History (hereafter AMH). 
3. Thomas D. Wilson, The Oglethorpe Plan: Enlightenment Design in Savannah and Beyond (Charlottesville: University of Virginia Press, 2012), 89; Edward J. Cashin, The Story of Augusta (Augusta, GA: Richmond County Board of Education, 1980), 9-10, 30-31, 224; John Linley, The Georgia Catalog: Historic American Buildings Survey (Athens, GA: University of Georgia Press, 1983), 93; "The City of Augusta," Augusta Chronicle. January 25, 1900. Macon, Georgia, has three downtown streets that have been 180 feet wide since their platting in the $1820 \mathrm{~s}$, but none of them is the city's main retail street. Columbus, Georgia, has the 164-foot-wide Broadway, originally platted as Broad Street in the 1820s. Therefore, the uniqueness that each city ascribed to its widest street(s) might better be understood as applying to the trio of Georgia fall line cities rather than to Augusta alone.

4. Florence Marye, Garden History of Georgia, 1733-1933 (Atlanta, GA: Peachtree Garden Club, 1933), 10; Georgianna Stark, "Thirty-five Years of Organized Gardening Have Produced 'Garden City of the South,", Augusta Chronicle-Herald, September 8, 1957, p. 6-C; Christopher C. Meyers, "Fruitland Nursery: A 'Horticultural Mecca,"' Georgia Historical Quarterly 99, no. 1/2 (Spring/Summer 2015): 48-80.

5. This article is part of my broader book project on Georgia's fall line cities of Augusta, Macon, and Columbus. These cities, which range in population from about 150,000 to 200,000 , are, like other smaller cities, especially southern cities, too often overlooked by urban historians who focus much more often on large cities in other regions; see Richard Harris, "A Portrait of North American Urban Historians," Journal of Urban History, published first online (September 21, 2018), doi: 10.1177) 0096144218801598. In the case of Augusta, only one historian, Edward J. Cashin, has published an extensive scholarly treatment of the city, and it is nearly forty years old and surveys almost 250 years; see Cashin, The Story of Augusta, 1980.

6. Bonj Szczygiel, “'City Beautiful' Revisited: An Analysis of Nineteenth-century Civic Improvement Efforts," Journal of Urban History 29, no. 2 (December 2003): 110, 113, 115-18.

7. Most scholars have looked at big plans for big cities and argued that the City Beautiful proved impractical, thereby bringing its demise, although more recently a few scholars have found signs of the movement's persistence. See, for example, Meredith Drake Reitan, "Beauty Controlled: The Persistence of City Beautiful Planning in Los Angeles," Journal of Planning History 13, no. 4 (November 2014): 296-321; John Pipkin, "Chasing Rainbows in Albany: City Beautiful, City Practical 1900-1925," Journal of Planning History 7, no. 4 (November 2008): 327-53; Robert Freestone, "Reconciling Beauty and Utility in Early City Planning: The Contribution of John Nolen," Journal of Urban History 37, no. 2 (March 2011): 256-77.

8. Wilson, Oglethorpe Plan, 135.

9. Historical studies of beautification rarely incorporate preservation. Likewise, preservation historians often identify the early twentieth-century shift from focusing on preserving individual buildings to whole districts, but they seldom include beautification planning in their analyses. Here, I make a distinction between beautification planning and landscape preservation. On the latter, see, for example, Richard Longstreth, ed., Cultural Landscapes: Balancing Nature and Heritage in Preservation Practice (Minneapolis: University of Minnesota Press, 2008). Exceptions include Michael Holleran, Boston's "Changeful Times": Origins of Preservation \& Planning in America (Baltimore, MD: Johns Hopkins University Press, 1998), chap. 5; Randall Mason, The Once and Future New York: Historic Preservation and the Modern City (Minneapolis: University of Minnesota Press, 2009). Likewise, studies of downtowns and central-city revitalization may examine the role of historic preservation or introduction of aesthetically pleasing amenities, but they seldom connect downtown development and redevelopment with city beautification. Alison Isenberg examines the municipal housekeeping movement of the early twentieth century but does not extend beyond concerns for cleaning and decluttering streetscapes; Alison Isenberg, Downtown America: A History of the Place and the People Who Made It (Chicago, IL: University of Chicago Press, 2005), chap. 1.

10. Daphne Spain, How Women Saved the City (Minneapolis: University of Minnesota Press, 2001), esp. chap. 1. 
11. "To Beautify a Pretty City," Augusta Chronicle, February 22, 1901, p. 5; "Memorial for A. M. Martin Jr.," Augusta Chronicle, March 3, 1901, p. 2.

12. "Boulevard and Park System Discussed by Col. D. B. Dyer," Augusta Chronicle, July 19, 1903, p. 8-A.

13. "Col. D. B. Dyer Talks of Macon's Development," Macon Telegraph, February 13, 1910, p. 7. On Kessler's park and boulevard planning in Kansas City, see William H. Wilson, The City Beautiful Movement (Baltimore, MD: Johns Hopkins University Press, 1994), 99-125.

14. Col. D. B. Dyer, "The Proposed Plan for Fifteen-mile Boulevard," Augusta Chronicle, March 25, 1906, p. 40; "Why Not Begin Building Boulevards?" (editorial), Augusta Chronicle, May 2, 1909, p. 4-C. Augusta's boulevard plan was far more ambitious than that in similarly sized Greenville, South Carolina, where the Boston landscape architecture firm Kelsey \& Guild proposed a boulevard that made a much tighter circle around the central city; Kelsey \& Guild, Beautifying and Improving Greenville, South Carolina: Report to the Municipal League. Greenville, South Carolina (Boston, MA: Kelsey \& Guild, 1907), 11, accessed September 4, 2018, https://catalog.hathitrust.org/Record/100963755.

15. "Augusta, Georgia," American Architect, May 26, 1909, 170-73.

16. 1911 Year Book of the City Council of Augusta, Ga., Augusta-Richmond County Public Library (hereafter ARCPL), 36; 1912 Year Book of the City Council of Augusta. Ga., ARCPL, 97; "Chamber of Commerce Begins Publicity in Northern Papers," Augusta Chronicle, March 4, 1913, p. 12.

17. Isenberg, Downtown America, chap. 1.

18. "Augusta Woman's Club Meeting," Augusta Chronicle, October 19, 1913, p. 3; “A 'City Beautiful' Campaign for Augusta" (editorial), Augusta Chronicle, February 13, 1916, p. 20; "Every Ward Stands Alone in 'The City Beautiful Campaign,"' Augusta Chronicle, February 26, 1916, p. 6.

19. "The Segregation Ordinance Fails," Augusta Chronicle, December 9, 1913, p. 7; John Dittmer, Black Georgia in the Progressive Era. 1900-1920 (Urbana: University of Illinois Press, 1980), 13; "Colored People to Have Part in 'The City Beautiful Campaign,"” Augusta Chronicle, February 23, 1916, p. 8.

20. "Five Thousand Citizens of Augusta Worked in the Effort Put Forth for City Beautiful Campaign," Augusta Chronicle, July 9, 1916, p. 5.

21. Cashin, The Story of Augusta, 218; "CCity Beautiful' Campaign to Go on with Renewed Vigor," Augusta Chronicle, March 31, 1916, p. 3.

22. Louise Thrash, "Love of Past Motivates Historic Preservation," Augusta Chronicle-Herald, August 15, 1982, Women of Today sec., p. 15.

23. Julia Lester Dillon, "Flowers and Vegetables Grow Where Rubbish Formerly Reposed," Augusta Chronicle, June 11, 1916, p. 21.

24. "Making Augusta the City Beautiful" (editorial), Augusta Chronicle, March 12, 1921, p. 6.

25. 1921 Year Book of the City Council of Augusta, Ga., ARCPL, 49; 1922 Year Book of the City Council of Augusta, Ga., ARCPL, 46-47, 50; 1923 Year Book of the City Council of Augusta, Ga., ARCPL, 51, 53-54; 1925 Year Book of the City Council of Augusta, Ga., ARCPL, 41; 1926 Year Book of the City Council of Augusta, Ga., ARCPL. 44.

26. 1928 Year Book of the City Council of Augusta, Ga., ARCPL, 50-51; Laurie Gregory, "Trees Bring City Beauty ... and Problems," Sunday Chronicle-Herald, February 8, 1976, p. 4C.

27. "History: The Sand Hills Garden Club, Augusta, Georgia," 1980, box 3, History of Civic Clubs (hereafter HCC), Augusta University Library Special Collections (hereafter AUL); Mary Turner, "Mrs. Cohen Wins National Honor as Well as Hearts of Augustans," Augusta Chronicle, January 25, 1972, p. 6. Sand Hills Garden Club was initially named the Augusta Garden Club but changed its name when it became a member club in the Garden Club of America to avoid duplicating the name of another member organization in Augusta, Virginia.

28. "History: The Sand Hills Garden Club, Augusta, Georgia"; "Thousands Attend Garden City's Famed Camellia Show," Augusta Chronicle, February 5, 1933, p. 1; "Garden Clubs, Rapidly Increasing, Make Augusta 'City Beautiful,"' Augusta Chronicle. February 10, 1933, p. 6. 
29. "Park Purchase Asked," Augusta Chronicle, March 25, 1936; 1936 Year Book of the City Council of Augusta, Ga., ARCPL, 7, 76.

30. "Council Committee Discusses Beautification Program Today," Augusta Chronicle, July 10, 1936, p. 1; "Symms Outlines 10-Year Beautification Objective for City Planning Group," Augusta Chronicle, August 16, 1936, pp. 1, 15. The commission consisted of six members including two nominated by city council, one by the Augusta Federation of Women's Clubs, one by Sand Hills Garden Club, and two by the Chamber of Commerce.

31. "Beautifying Broad Street" (editorial), Augusta Chronicle, July 19, 1936, p. 4; "Beautify Augusta" (editorial), Augusta Chronicle, February 12, 1937, p. 4-A.

32. 1936 Year Book of the City Council of Augusta, Ga., ARCPL, 74; 1937 Year Book of the City Council of Augusta, Ga., ARCPL, 74, 136; 1938 Year Book of the City Council of Augusta, Ga., ARCPL, 128; 1939 Year Book of the City Council of Augusta, Ga., ARCPL, 75; "City Beautification Program Outlined by Capt. Robertson at Luncheon of Woman's Club," Augusta Chronicle, October 7, 1936, p. 5.

33. "Landscape Specialists to Begin Beautification Survey Here Today," Augusta Chronicle, April 28, 1937, p. 10; "Augusta's Beautification and Traffic Improvement Program Given Approval," Augusta Chronicle, July 7, 1937, p. 1.

34. Home Owners' Loan Corporation Residential Security Map, Augusta, Georgia, September 15, 1937, in Robert K. Nelson, et al., "Mapping Inequality," in American Panorama, ed. Robert K. Nelson and Edward L. Ayers, accessed July 29, 2018, https://dsl.richmond.edu/panorama/redlining/\#loc=13/33.4790/-81. 9980\&opacity $=0.8 \&$ city =augusta-ga; Jesse Meisenhelter, "How 1930s Discrimination Shaped Inequality in Today's Cities," NCRC, March 27, 2018, accessed July 29, 2018, https://ncrc.org/how-1930s-discrimi nation-shaped-inequality-in-todays-cities/. Two other Georgia fall line cities were also among the most heavily redlined: Macon ranked first, while Columbus was sixth.

35. "Program to Beautify Gwinnett Street Approved Here," Augusta Chronicle, June 17, 1938, p. 9; "Realtor Named Chairman Gwinnett Beautification Job," Augusta Chronicle, June 30, 1938, p. 3.

36. "Augusta Negroes Celebrate Gwinnett Street's Paving," Augusta Chronicle, August 4, 1938, p. 3. The paternalistic tone and limited attention to including the black community in beautification planning in Augusta echoes that in other southern cities in the era of Jim Crow. See, for example, Karen Sayen Kirkland, The Hogg Family and Houston: Philanthropy and the Civic Ideal (Austin: University of Texas Press, 2009), 65.

37. Jason Scott Smith, Building New Deal Liberalism: The Political Economy of Public Works, 1933-1956 (New York: Cambridge University Press, 2006), 203; "Council Body Cuts Budgets of Three City Departments," Augusta Chronicle, February 4, 1939, p. 1.

38. Thomas H. Reed and Doris D. Reed, Report to the Citizens: A Survey of the Government of the City of Augusta, Georgia, May 1945 (Augusta, GA: Augusta Citizens Union, 1945), 41-42, 60, ARCPL; Year Book of the City Council of Augusta, Ga., 1940-1948, ARCPL.

39. "City Beautiful" (editorial), Augusta Chronicle, December 9, 1945, p. 6.

40. Turner, "Mrs. Cohen Wins National Honor," 1972; "A Good Beginning" (editorial), Augusta Chronicle, January 5,1949 , p. 4.

41. Florence Hill, "Down to Earth" (column), Augusta Chronicle, October 30, 1949, p. 11-C; "Parks Committee Begins Program," Augusta Chronicle, January 8, 1949, p. 8; "City Department Is Planning Planting along Lower Greene," Augusta Chronicle, January 27, 1950, p. 3-B; “City’s Beautification Program Is Being Pushed at Top Speed," Augusta Chronicle-Herald, January 15, 1950, p. 2-D; "Fall Beautification Program Is Started by City Workers," Augusta Chronicle, September 20, 1950, p. 3; "Augusta the Beautiful" (editorial), Augusta Chronicle, March 11, 1949, p. 4; Year Book of the City Council of Augusta, Ga., 1949-1957, ARCPL.

42. Daniel Lang, "Camellias and Bombs," The New Yorker, July 7, 1951, 37-43, box 2, folder 5, Lester Moody Collection (hereafter LMC), AMH; "New Atomic Bomb Plant Hits Augusta with a Bang," Business Week (November 10, 1951), reprint, no pagination, box 2, folder 5. LMC. See also Kari Frederickson, Cold War Dixie: Militarization and Modernization in the American South (Athens, GA: University of Georgia Press, 2013). 
43. "Historical Restoration Unit Forms," Augusta Chronicle, June 3, 1965. On Savannah's preservation movement, see Robert Hodder, "Savannah's Changing Past: Historic Preservation Planning and the Social Construction of a Historic Landscape, 1955 to 1985," in Planning the Twentieth-century American City, ed. Mary Corbin Sies and Christopher Silver (Baltimore, MD: Johns Hopkins University Press, 1996), 361-82.

44. Thrash, "Love of Past," 1982; Meeting of Petitioners for Incorporation of Historic Augusta, Inc., September 21, 1965, Meeting Minutes, Historic Augusta Inc. (hereafter HAI).

45. In 1928 and 1933, respectively, the Young Men's Library Association and the Augusta Museum moved to the former Academy of Richmond County, constructed in 1802. Ware's Folly, the landmark 1818 mansion of onetime Augusta mayor and US senator Nicholas Ware, was spared demolition for a service station in 1937 when Olivia Herbert, a New Jersey transplant, provided funds to turn it into the Gertrude Herbert Institute of Art as a memorial to her deceased daughter. In 1954, the Junior League of Augusta bought the Old Government House, built in 1801, and made it their headquarters.

46. Meeting of Board of Trustees, April 26, 1966, Meeting Minutes, HAI; Mary Turner, "Historic Augusta Schedules Meeting to Review Accomplishments, Plan Future," Augusta Chronicle-Herald, May 7, 1967, p. 1-D; Meeting of Historic Augusta Inc., September 10, 1968, Meeting Minutes, HAI; Drawings by John Rush, News Bulletin (Historic Augusta Inc.), 1:3 (March 1969), HAI. On the demolitions associated with creating Colonial Williamsburg, see Anders Greenspan, Creating Colonial Williamsburg: The Restoration of Virginia's Eighteenth-century Capital, 2nd ed. (Chapel Hill: University of North Carolina Press, 2009).

47. Hodder, "Savannah's Changing Past," 370.

48. Billy Warren, "Planners Protect Residential District," Augusta Chronicle, May 11, 1965, p. 13. On the presumed connection between race and property values, see especially David M. P. Freund, Colored Property: State Policy \& White Racial Politics in Suburban America (Chicago, IL: University of Chicago Press, 2009); LeeAnn Lands, The Culture of Property: Race, Class, and Housing Landscapes in Atlanta. 1880-1950 (Athens, GA: University of Georgia Press, 2009).

49. Mary Turner, "Historic Augusta Members See Slides of Savannah's Restoration Program," Augusta Chronicle, May 11, 1967, p. 4B.

50. "Annual Meeting," News Bulletin, 1, no. 4 (May 1969), HAI.

51. In this way, Augusta mirrored Savannah. See Hodder, "Savannah's Changing Past," 368.

52. "Merchants Plan Meter Discussion," Augusta Chronicle, September 24, 1941, p. 4; "Parking Meters to Be Installed," Augusta Chronicle, September 10, 1946, p. 1.

53. Robert Lamb, "Needed: A Plan for 'Face-lifting' on Broad Street," Augusta Chronicle-Herald, November 25, 1962, p. 1B; "We Should Heed the Experts" (editorial), Augusta Chronicle, March 26, 1963, p. 6; "Mayor Urges Cutting Isle Parking," Augusta Chronicle, August 6, 1964, Georgia Edition, p. 1.

54. Ramsis W. Baghose, Central Business District Study, Augusta, Georgia (Augusta, GA: Augusta-Richmond County Planning Commission, Summer, 1962), 18-20, 23-25, 29, University of Illinois at UrbanaChampaign via HathiTrust Digital Library, accessed July 31, 2018, https:/catalog.hathitrust.org/Record/ 102185420 .

55. Augusta Commercial Areas Study Committee, Downtown Augusta: A Plan for Expansion and Revitalization of the Central Area of Augusta, Georgia (Augusta, GA: Commercial Areas Study Committee of Augusta, 1968), 8-9, 17, 27, 34-42, ARCPL.

56. Augusta-Richmond County Planning Commission, Community Facilities Plan, Vol. I: Historic Preservation, City Beautification (Augusta, GA: Augusta-Richmond County Planning Commission, 1968), 50, 58-59, ARCPL.

57. Planning Commission, Community Facilities Plan, 26, 36, map 4 (following p. 39), map 5 (following p. 70 ).

58. Norman C. Larson, "A Master Plan for Historic Augusta," August 1968, Meeting Minutes, HAI.

59. Ray Hill, "A Look-back at the Hard Times of Five Years Ago," News Bulletin 6:1 (March 1975), HAI; Thomas P. Mayes, "Downtown Augusta Plan," Sunday Chronicle-Herald, December 21, 1969, p. 1 B. 
60. William Winn and D. L. Inman, "Augusta, Georgia," in Southern Regional Council, Augusta. Georgia and Jackson State University: Southern Episodes in a National Tragedy (Atlanta, GA: Southern Regional Council, June, 1970), 21-34, Augusta, Georgia, Race Riots, 1970, MSS/210, AUL.

61. Winn and Inman, "Augusta, Georgia," 2, 7, 10.

62. Fourth Annual Meeting of Historic Augusta Inc., May 27, 1970, Meeting Minutes, HAI; Hill, "A Lookback," 1975.

63. Seventh Annual Meeting of Historic Augusta Inc., May 10, 1973, Meeting Minutes, HAI.

64. Ninth Annual Meeting of Historic Augusta Inc., May 22, 1975, Meeting Minutes, HAI; Twelfth Annual Meeting of Historic Augusta Inc., May 19, 1977, Meeting Minutes, HAI.

65. Margaret Twiggs, "City Hall," Sunday Chronicle-Herald, April 8, 1973, p. 4D.

66. 1974 Year Book of the City Council of Augusta, Ga., 86, ARCPL; 1975 Year Book of the City Council of Augusta, Ga., 2, 88, ARCPL.

67. Gregory, "Trees Bring City Beauty," 1976; John S. Carter, "Group of Enthusiasts Wants Better Care for Augusta Trees," Augusta Chronicle, September 29, 1978, p. 2B; Trees and Parks Department annual reports, in Year Book of the City Council of Augusta, Ga., 1953-1982, ARCPL.

68. Martin Shartar, "Augusta's Renaissance," Augusta Magazine, Winter 1976, 24, 27; "Pei Retained to Spearhead Downtown Revitalization," Augusta Chronicle, April 19, 1974, p. 1 B.

69. "Public May View Downtown Mode1," Augusta Chronicle, September 18, 1974, p. 13; "New Life" (editorial), Augusta Chronicle, September 19, 1974, p. 4-A.

70. Frank Adams, "\$4 Million Plan Is Unveiled for New-look Broad Street," Augusta Chronicle, September 18, 1974, p. 1; Frank Adams, "Community Effort Urged to Finance Downtown Plan," Augusta Chronicle, September 18, 1974, p. 1.

71. Shartar, "Augusta's Renaissance," 28; Anne Osborne, "Broad Street Remembered," Augusta Magazine, Winter 1976, 23.

72. John S. Carter, "Facades Important to City," Augusta Chronicle, September 12, 1979, p. 4P.

73. Meeting of Board of Trustees, October 4, 1979, Meeting Minutes, HAI; Meeting of Executive Committee, November 28, 1979, Meeting Minutes, HAI.

74. Historic Properties Survey (Augusta, GA: Historic Augusta Inc.; Augusta-Richmond County Planning Commission, 1983), 53, HAI; Meeting of Executive Committee, March 13, 1980, Meeting Minutes. HAI; "Historic Augusta Buys Downtown Building," Augusta Chronicle, July 8, 1980, p. 6B; "Face-lifting on Broad Street," News Bulletin, 13:1 (Fall 1982), HAI.

75. "Adler to Speak to Trustees," News Bulletin, 8:1 (Fall 1977), HAI; Johnie Hilburn, "Historic Augusta Visits Low-income Rehab in Savannah," News Bulletin, 9:2 (Spring 1978). HAI. On Savannah's Victorian District, see Hodder, "Savannah's Changing Past," 372-76.

76. H. Allen Strickland Jr. to Wilson P. Mason, May 4, 1970, Meeting Minutes, HAI; G. Baker, "Olde Towne, Old Neighborhood But New Name and Outlook," Augusta Magazine, Fall 1979, 21, ARCPL.

77. Historic Properties Survey, 34-35.

78. John Sorrells, "2 Stores on Broad to Close," Augusta Chronicle, June 2, 1978, p. 1; John S. Carter, "Cullum's to Close Store at Downtown Location," Augusta Chronicle, September 21, 1978, p. 1B.

79. On the Rouse Company's role in downtown revival, see especially Nicholas Dagen Bloom, Merchant of Illusion: James Rouse: America's Salesman of the Businessman's Utopia (Columbus: Ohio State University Press, 2005), chap. 6; Isenberg, Downtown America, chap. 7; Aaron Cowan, A Nice Place to Visit: Tourism and Urban Revitalization in the Postwar Rustbelt (Philadelphia, PA: Temple University Press, 2016), chap. 5.

80. Marjorie Mayfield, "McIntyre Unveils Proposals for Downtown," Augusta Chronicle, February 25, 1982, p. 1 A.

81. American City Corporation, Downtown Augusta, Georgia Development Program. Prepared for the City of Augusta, Georgia, and Augusta Tomorrow. Inc. (Columbia, MD: American City Corporation, September 
1982), 34-35, 37, 39, 43, 45, accessed September 5, 2018, http:/www.augustatomorrow.com/wp-content/ uploads/2014/07/1982-Master-Plan.pdf.

82. American City Corporation, Downtown Augusta, Georgia Development Program, 13.

83. 1975 Year Book of the City Council of Augusta, Ga., 4, ARCPL; Dan Rowland, "History, Problems of 'Terri' Outlined," Augusta Chronicle, April 12, 1973, p. 2B.

84. Jenny Munro, "Historian Begins Study of Augusta Blacks' Past," Augusta Chronicle, August 27, 1980, p. 2B; 1981 Year Book of the City Council of Augusta, Ga., 85, ARCPL.

85. American City Corporation, Downtown Augusta, Georgia Development Program, 31, 46, 49-50.

86. American City Corporation, Downtown Augusta, Georgia Development Program, 32, 39, 44-45.

87. Meg Mirshak, "Vision for Riverwalk Is Different from Reality," Augusta Chronicle, July 27, 2013, accessed September 5, 2018, https://www.augustachronicle.com/article/20130727/NEWS/307279883.

88. Ibid.

89. John Barnes, "Let's Take a Cold, Hard Look at Our Town," Sunday Chronicle-Herald, September 13, 1970 , p. 3E. It is worth noting that the same nickname was affixed to Augusta, Maine, a reminder that the negative perceptions of Augusta, Georgia, reflect a broader tendency to subject cities, especially smaller ones or those that have struggled with economic adversity, to unfavorable comparison with larger or more admired cities.

90. ICON Architecture, George Henry George, The Woodhurst Partnership, and Slate Blue Design, et al., 2009 Master Plan for a Sustainable Future, Part 2: Final Report (Boston, MA: ICON Architecture, 2009), 5, 31-33, accessed September 10, 2018, https://www.augustatomorrow.com/wp-content/uploads/2014/07/ 2009-Master-Plan-Final-Report-r.pdf. The North Augusta Greeneway was named for the city's former Mayor Thomas W. Greene (1985-1997).

91. John Nolen, City Plan: Columbus, Georgia (Cambridge, MA: John Nolen, 1926), accessed September 4, 2018, https://www.columbusga.gov/planning/pdfs/Nolan_City_Plan-1926b.pdf. Two other smaller regional cities, Columbia and Greenville, South Carolina, both commissioned city plans by Kelsey \& Guild of Boston; see Daniel J. Vivian, "Kelsey and Guild"-South Carolina Encyclopedia (University of South Carolina, Institute for Southern Studies), accessed September 4, 2018, http://www.scencyclope dia.org/sce/entries/kelsey-and-guild/.

\section{Author Biography}

J. Mark Souther is a professor of history at Cleveland State University in Cleveland, OH. His most recent book is Believing in Cleveland: Managing Decline in "The Best Location in the Nation" (Temple University Press, 2017). 